\title{
An Overview on the Development of mRNA-Based Vaccines and Their Formulation Strategies for Improved Antigen Expression In Vivo
}

\author{
Md. Motiar Rahman ${ }^{1, *}$, Nan Zhou ${ }^{1}$ (D) and Jiandong Huang ${ }^{1,2}$ (D) \\ 1 Institute of Synthetic Biology, Shenzhen Institute of Advanced Technology (SIAT), Chinese Academy of \\ Sciences (CAS), Shenzhen 518055, China; nan.zhou@siat.ac.cn (N.Z.); jdhuang@hku.hk (J.H.) \\ 2 Faculty of Medicine, School of Biomedical Sciences, The University of Hong Kong, Hong Kong 999077, China \\ * Correspondence: md_motiar@siat.ac.cn
}

Citation: Rahman, M..M.; Zhou, N.;

Huang, J. An Overview on the

Development of mRNA-Based

Vaccines and Their Formulation Strategies for Improved Antigen Expression In Vivo. Vaccines 2021, 9, 244. https://doi.org/10.3390/ vaccines 9030244

Academic Editor: Ralph A. Tripp

Received: 20 January 2021

Accepted: 23 February 2021

Published: 11 March 2021

Publisher's Note: MDPI stays neutral with regard to jurisdictional claims in published maps and institutional affiliations.

Copyright: (c) 2021 by the authors. Licensee MDPI, Basel, Switzerland. This article is an open access article distributed under the terms and conditions of the Creative Commons Attribution (CC BY) license (https:// creativecommons.org/licenses/by/ $4.0 /)$.

\begin{abstract}
The mRNA-based vaccine approach is a promising alternative to traditional vaccines due to its ability for prompt development, high potency, and potential for secure administration and low-cost production. Nonetheless, the application has still been limited by the instability as well as the ineffective delivery of mRNA in vivo. Current technological improvements have now mostly overcome these concerns, and manifold mRNA vaccine plans against various forms of malignancies and infectious ailments have reported inspiring outcomes in both humans and animal models. This article summarizes recent mRNA-based vaccine developments, advances of in vivo mRNA deliveries, reflects challenges and safety concerns, and future perspectives, in developing the mRNA vaccine platform for extensive therapeutic use.
\end{abstract}

Keywords: IVT mRNA; mRNA vaccine; electroporation; protamine; LNPs

\section{Introduction}

Vaccines protect against millions of microbes and save thousands of lives from diseases each year [1]. Due to the use of extensive vaccines, the smallpox-causing virus (variola) has been eliminated and the cases of measles, polio, and various other childhood ailments have significantly declined throughout the world [2]. Traditional vaccine technologies including subunit vaccines and, live attenuated (or weakened) and inactivated (or killed) pathogens, offer long-lasting protection against various lethal ailments [3]. Despite this achievement, there exist key obstacles for the development of successful vaccines against diverse infectious disease-causing pathogens, particularly those better efficient to avoid adaptive immunity $[1,4]$. Besides, for the utmost evolving virus vaccines, the major difficulty is not the efficiency of established technologies but the demand for quick and large-scale production. Moreover, traditional vaccine technologies might be invalid for non-infectious disorders like cancer. Therefore, there is an urgent need for the progression of more versatile and effective vaccine platforms.

Nucleic acid-based treatments have developed as promising substitutes for traditional vaccine approaches. In animals, the first data of the use of successful in vitro transcribed (IVT) mRNA was reported in 1990, while reporter mRNAs were administered into in vivo mice model, and subsequently, protein expression was identified [5]. In 1992, a later study revealed that the use of messenger RNA encoding vasopressin in the brain hypothalamus can induce biological effects in rats [6]. Nonetheless, these primary but significant results could not make considerable investments in evolving mRNA-based vaccines, mainly due to concerns related to higher innate immunogenicity, mRNA instability, as well as inefficient drug delivery in vivo. Alternatively, the field approached DNA- and/or protein-based therapeutics $[7,8]$. Nonetheless, since the discovery of mRNA, it has been known the matter of consistent basic as well as applied research for many ailments $[9,10]$. In the initial decades 
of mRNA discovery, the main attention was on comprehensive investigations of structural as well as functional characteristics of eukaryotic mRNA and its metabolism. This is in order to make approaches for mRNA-based recombinant technology readily accessible to a wider research arena. In the late 1990s, preclinical investigation of IVT mRNAs was introduced for various applications, such as protein replacement and vaccination tools for cancer as well as infectious diseases [6,11-18]. Therefore, accumulated information allowed the latest scientific and technological improvements to overcome various difficulties related to mRNA, including its short half-life as well as adverse immunogenicity.

The administration of the mRNA-based vaccine has some benefits over subunit, live attenuated and inactivated virus, and DNA vaccines. Firstly, safety: there is no possible concern of insertional mutagenesis or infection since mRNA is non-integrating and noninfectious. Moreover, mRNA is generally destroyed under normal cellular conditions, and its in vivo half-life could be controlled via the use of diverse modification systems as well as delivery methods [19-22]. Besides, the innate immunogenicity of the mRNA could be downregulated to enhance the safety profile $[19,22,23]$. Secondly, efficacy: several modifications provide mRNA not only high stability but also translatability $[19,22,23]$. Efficient in vivo delivery of mRNA can be obtained by formulating them into carrier molecules such as polymers, peptides, lipid nanoparticles, micelles, allowing faster uptake and enhancing protein expression in the cytosol [20,21]. mRNA is considered the minimal hereditary material; hence, anti-vector mediated immunity is prevented, and these vaccines could be used recurrently. Finally, production: mostly due to the high yielding capability of IVT mRNA during transcription reactions, these vaccines have the potential for fast, low-priced, as well as scalable manufacturing.

The mRNA vaccine is a rapidly developing field; many preclinical investigations have been reported over the past few years [24-30]. Multiple human clinical trials have been initiated IVT mRNA-based therapeutics as protein-replacement therapy in the field of oncology [31-34], cardiology [35,36], endocrinology [37], hematology [38,39], pulmonary medicine [38,40], or the treatment of other diseases [14,41]. To further advance this revolutionary approach, unresolved issues like targeted mRNA delivery and its intricated pharmacology require to be developed.

Here, we review up-to-date mRNA-based vaccine approaches, describe the latest outcomes, highlight challenges and safety profiles in human trials, as well as recent successes. In addition, we demonstrate an inclusive summary of mostly used, protamine-, lipid nanoparticles- and electroporation/nanoparticle-based, drug deliveries, and their recent findings in vaccine development. Additionally, finally, the authors provide perceptions on the future opportunity of mRNA therapeutics. The reports propose that mRNA therapeutics can overcome various challenges in the development of vaccines for cancer and infectious ailments.

\section{Structure of IVT mRNA for Improved Translation}

Eukaryotic mRNA is generally transcribed in the nucleus, transported to the cytoplasm via nuclear export, and leading to protein synthesis. On the other hand, IVT mRNA must transfect into the cytosolic space from the extracellular matrix. Several factors are important for the successful delivery of IVT mRNA into the cells; (a) to overcome highly efficient ribonuclease of extracellular matrices, (b) to cross passive diffusion hindering cell membrane of the negatively charged mRNA macromolecules. Eukaryotic cells can engulf unprocessed mRNA very rapidly, however; the uptake efficiency and cytosolic transfer of IVT mRNA are very low in major cell types, which can be developed by modification of IVT mRNA with various complexing agents. This formulation prevents mRNA from ribonuclease-mediated degradation and facilitates cellular mRNA uptake. Apart from these, various techniques like electroporation could be used for transferring ex vivo mRNA rapidly into cells [9].

Significant efforts have been made to modify structural components of the in vitro transcribed mRNA, specifically the coding region, the $5^{\prime}$ cap, the poly(A) tail, and untrans- 
lated regions (UTRs) (both at $5^{\prime}$ - and $3^{\prime}$ regions), to sequentially increasing its intracellular stability as well as translational efficiency (Figure 1). In fact, these advancements eventually lead to the synthesis of substantial amounts of protein over a longer time frame; ranging from a few minutes to longer than 1 week [42-44]. In the cytoplasm, substituting rare codons with recurrently used identical codons that show copious cognate tRNA is a usual habit to boost mRNA translation [45], while this model has been questioned in their accuracy [46]. Latest studies demonstrate that codon-optimization may disturb protein folding as well as function, enhance immunogenicity, and decrease efficiency. The analyses also reported that this strategy might develop difficulty in codon usage and challenges the scientific platforms for codon-optimization. Subsequently, codon-optimization might be unable to specify an optimal approach for boosting protein expression and may reduce the safety as well as the efficiency of mRNA-based therapeutics [46]. Improvement of G:C content represents an alternative sequence optimization that has been revealed to enhance steady-state mRNA concentrations in vitro [47] as well as protein expression in vivo [22]. While protein expression could be improved positively by inducing nucleosides modification, this modification might impact on the mRNA secondary structure [48], the kinetics and efficiency of protein synthesis and concurrent protein folding [49,50], and the induction of epitopes existing in other reading frames [46]. All these factors might possibly affect the level of immune induction. The kind of opportunities existing for modulating mRNA pharmacology is still unknown, and a greater level of understanding regarding mRNA-binding factors along with its binding sites might open a new door for engineering mRNA construct with various pharmacokinetic properties.

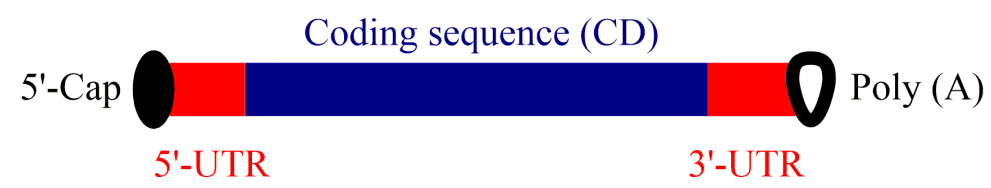

Figure 1. mRNA structure for optimal protein expression in vivo. An improved mRNA candidate contains 5'-cap, poly(A), 5'- and 3'-UTRs, and the coding sequence.

\section{Effect of Nucleoside Modification in Antigen Expression}

Natural RNAs consist of adenosine triphosphate (ATP), guanosine triphosphate (GTP), uridine triphosphate (UTP), and cytidine triphosphate (CTP). In the case of nucleotide modification, a particular nucleoside undergoes modification after the transcription process. Owing to various limitations, presently, the easiest way to synthesize chemically modified RNA involves the in vitro RNA synthesis, in which a single nucleotide out of four fundamental nucleotide triphosphates (NTPs) is substituted with an analogous modified NTP [51]. In these primary transcripts, one selected base is replaced by an altered nucleotide at each location.

The latest analyses have revealed that the incorporation of naturally occurring nucleosides during post-translational modification has proven beneficial effects for offering low immunogenicity of IVT RNA [52]. For example, IVT mRNA having pseudouridine modification exhibited increased RNA stability and protein synthesis [19,51]. However, while RNA can induce the immune system via stimulation of toll-like receptors (TLR3, TLR7, and TLR 8) [53-55], incorporation of modified nucleosides into mRNAs, such as pseudouridine ( $\Psi)$, 5-methylcytidine (m5C), N6-methyladenosine (m6A), 2-thiouridine (s2U), or 5-methyluridine (m5U) (Figure 2), reduced its activity by considerably decreasing cytokine concentrations and biomarker efficacy in dendritic cells (DCs) [51]. This method, therefore, inhibits TLRs-mediated recognition and induces immunological defenses against the IVT mRNA [19]. Moreover, in bids to enhance and increase protein expression time, purification of IVT mRNA by HPLC was useful since this method eliminates dsRNA impurities, which caused lower production of IFN-1 as well as proinflammatory cytokines [23]. The Hartmann group further demonstrated that nucleoside modifications, for example, $\Psi$ and s2U, prevented $5^{\prime}$-triphosphate RNA-induced stimulation of retinoic acid-inducible 
protein I (RIG-I), an alternative RNA-responsive immune sensor [52]. Hence, if any of the nucleoside modified IVT mRNAs would have translatability and also prevent in vivo innate immune activation, such RNA might be considered as a new therapeutic intervention not only for protein replacement but also for vaccination platform. To this line, Kariko et al. [19] investigated modified mRNAs in terms of their translational efficacy and immune properties in vivo. They reported that naturally occurring pseudouridine incorporation into mRNA protect RNA-induced immune activation both in vivo and in vitro and also increases the translational ability of the IVT RNA. These properties and the simplicity of producing such engineered mRNA by transcription reaction make mRNA a potential tool for the expression of any type of protein in either in vitro or cellular environment [19].
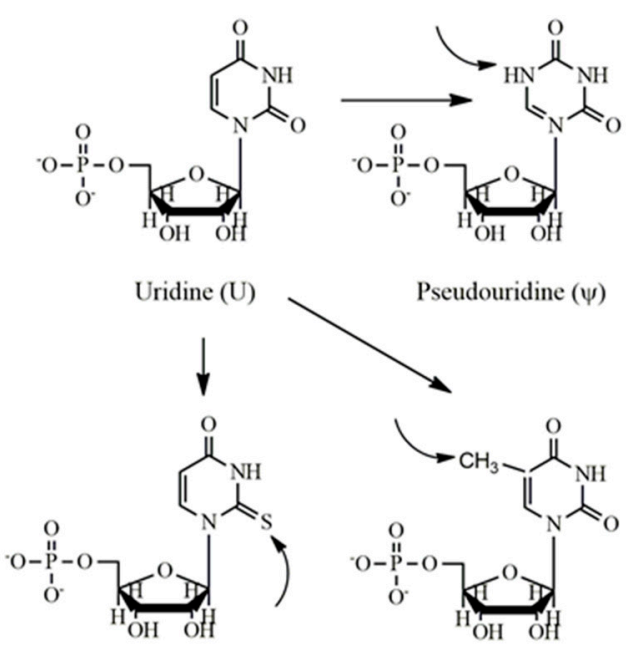

2-Thiouridine (s2U)

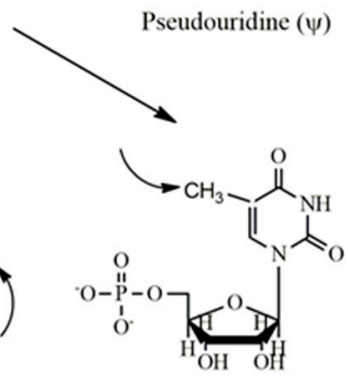

5-Methyluridine (m5U)<smiles>Nc1ccn(C2CCCC2)c(=O)n1</smiles>

Cytidine (C)

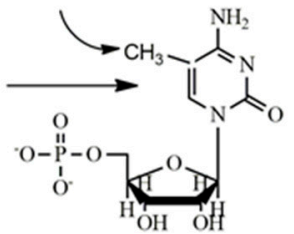

5-Methylcytidine (m5C)

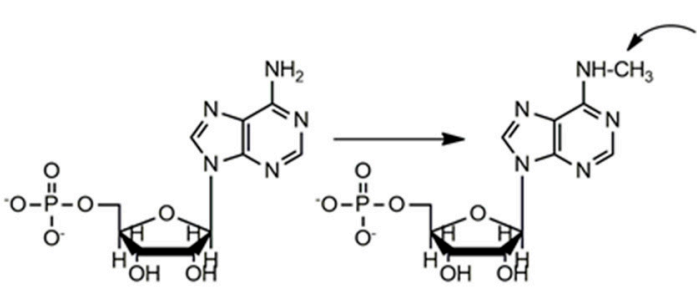

Adenosine (A)

Figure 2. Nucleoside bases usually modified in the vaccination process. Uridine $(\mathrm{U})$ is generally modified to pseudouridine $(\psi)$, 2-thiouridine (s2U) and 5-methyluridine, cytidine (C) to 5-methylcytidine, and adenosine (A) to 5-methyladenosine (m5A).

Studies have shown that nucleoside-modified RNA molecules encoding E glycoprotein and prM protein of Zika virus were encapsulated in LNPs (lipid-nanoparticles) [56]. Intradermal injection of a single low-dose of these proteins induced potent and long-lasting virus-neutralizing antibodies titer and therefore, protect against Zika virus challenges only by 30 and $50 \mu \mathrm{g}$ mRNAs in mice as well as nonhuman primates, respectively. Nucleoside modification studies have also been demonstrated in recent studies using various antigens such as OVA [57], Luc; HIV-1 Env; ZIKV prM-E; and influenza virus HA [58], EBOV GP [59], luciferase (Luc), or erythropoietin (EPO), or scrambled EPO coding region (scramble) [60], etc.

\section{Formulations of mRNA for In Vivo Drug Delivery}

The mRNA is generally synthesized in a cell-free condition by transcription reaction from a DNA template. Since the mRNA candidates need to cross membranous lipids, various nanoparticles (protamine, LNPs, lipid polymers hybrid-, gold- and polymeric nanoparticles), and cell-based delivery were optimized as tools to load and deliver RNA into the cytosol [61]. This review summarized the application of APCs (antigen-presenting cells) and nanoparticles (protamine, LNPs) in mRNA delivery with recent examples of clinical trials.

\subsection{Protamine}

Protamine is a positively charged natural protein that has an outstanding ability to bind with nucleic acid-like mRNA (Figure 3) and improved its uptake and transfection ability [62]. It has been shown that positively charged protamine could efficiently form a complex with messenger RNA through electrostatic interaction [63] and this complex may 
act as a danger signal and stimulates murine cells via MyD88-specific signaling including TLR7 and TLR8 [62]. Hoerr and colleagues revealed that this complex destroys within 2 hours following the incubation in the serum sample, which restricts their capabilities for endurance in the in vivo circulation [17]. They subsequently demonstrated that incompletely degraded protamine/mRNA complex can still show immunostimulatory action for more than $100 \mathrm{~h}$ [62]. It was also reported that protamine-complexed mRNA intensely stimulated a variety of white blood cells (WBCs) including B lymphocytes, granulocytes, and natural killer cells, and notably, elicited overall immune response compared to that of protamine-complexed DNA $[17,62]$.
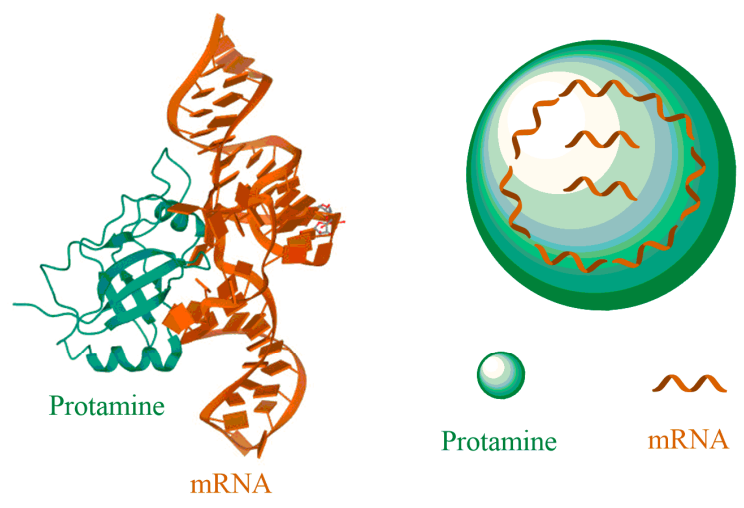

(A) mRNA-protamine complex
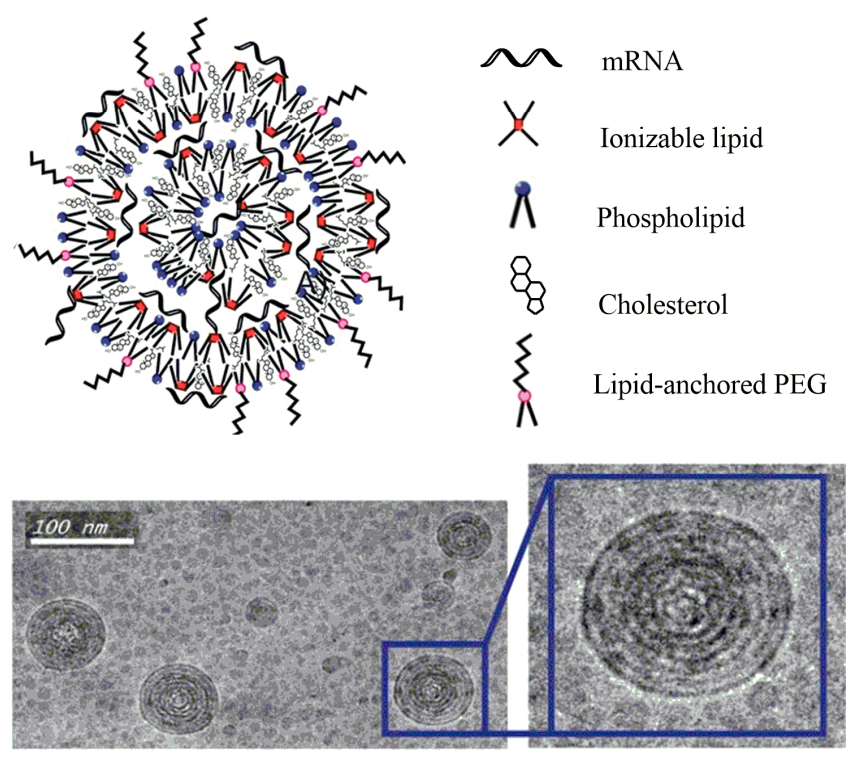

(B) mRNA-LNPs complex

Figure 3. Formulations of mRNA with nanobiomaterial for in vivo drug delivery. (A) Protaminecomplexed mRNA for drug delivery. (B) Synthetic components and electron microscopy images of various LNPs. LNPs have been reported to synthesize by mixing anionic mRNA with lipophilic compounds in ethanol using a microfluidic device. At lower $\mathrm{pH}$, the lipid-mRNA complex can accelerate both endocytosis as well as endosomal escape. Phospholipid used during the formulation process gives structural integrity to the lipid bilayers and can contribute to the endosomal release of the mRNA to the cytoplasm. Cholesterol assists to stabilize lipid nanoparticles and stimulates membrane fusion. The lipid-coated PEG (poly-ethylene-glycol) prevents the aggregation of LNP and decreases nonspecific interactions (up). Cryogenic transmission electron microscopy image indicates that the lipid nanoparticles have a spherical shape consisting of a multilamellar structure (bottom) (Adapted with permission with little modification from [57]). 
Weide et al. [28] reported the efficiency of protamine/mRNA complex by experimental analysis of intradermally-inoculated protamine/mRNAs complex that encodes for a variety of enzymes, such as Tyrosinase (an enzyme that helps to catalyze melanin formation), Melan-A (a melanoma antigen), gp100 (a protein included in the maturation of melanosome), Survivin (a protein which involves in the maintenance of apoptosis) of metastatic melanoma patients, MAGE-A1 (a melanoma antigen) and MAGE-A3 (a melanoma antigen) [28]. No adverse effects were observed higher than mild to moderate (grade II level) and overall, a complete clinical response, such as substantial result on the rate of immunosuppressive cells and rise of antigen-specific T cells was witnessed.

CureVac (Tübingen, Germany) recently studied the use of protamine/mRNA complex. In vivo analysis has shown that an mRNA vaccine (a two-component vaccine, RNActive) consists of both free and protamine/mRNA complex evolved an effective antigen expression and induced TLR7-mediated immune stimulation [64]. An efficient adaptive immune response with both humoral and $\mathrm{T}$ lymphocytes-mediated immunity was also obtained which exhibited not only therapeutic efficacy but also prophylactic activity against a tumor. In a separate study, CureVac has explored an analysis on castrate-resistant prostate cancer patients using protamine-complexed mRNA encoding for prostate-specific membrane antigen (PSMA), prostate-specific antigen (PSA), six transmembrane epithelial antigen of the prostate 1 (STEAP1), and prostate stem cell antigen (PSCA) [65]. After intradermal injection, $80 \%$ of the patients showed immune induction against the administered mRNA antigen and $60 \%$ against multiple antigens, which eventually interrelated with prolonged survival [65].

Using protamine-complexed mRNA, the Petsch group [66] reported that intradermal injection of mice with two component-mRNA encoding full-length hemagglutinin from H1N1 influenza A virus (A/Puerto Rico/8/1934) stimulated efficient seroconversion along with virus-neutralizing antibody titers in all immunized mice. Immune induction was long-durable and protected animals against influenza A virus challenge of the H1N1, H3N2, and H5N1 strains [66]. The efficiency of the two-component CureVac vaccine was further reported in pigs and ferrets [67].

In 2016, CureVac explored the protamine-mRNA complex to induce an immune response against the rabies virus. In that study, non-replicating rabies glycoprotein (RABVG) encoding mRNA was optimized to mediate potent virus-neutralization in mice and domestic pigs. The analysis reported an exceptional induced anti-rabies immunity in both animals. More notably, protamine-complexed RABV-G mRNA inoculated mice were protected from lethal intracerebral rabies infection. Consequently, the cellular and humoral immune responses noticed in non-human primates by RABV-G mRNA against rabies infection were superior over licensed vaccines Rabipur (LIC) and HDC [68]. Some of the currently used protamine-complexed mRNA vaccines with their clinical efficacy have been reviewed in Table 1.

Table 1. Protamine-mRNA formulated vaccines.

\begin{tabular}{cccc}
\hline Target mRNA & Stage & Findings & Ref. \\
\hline$\beta$-gal and GFP & $\begin{array}{c}\text { HeLa-K cells injected into B6 } \\
(\mathrm{H} 2) \text { and BALB/c mice }\end{array}$ & $\begin{array}{c}\text { Successful CTL response, } \\
\text { dependent on injection site }\end{array}$ & [17] \\
$\beta$-gal or CMV pp65 & Murine BM-DC & $\begin{array}{c}\text { Stimulated mouse BM- DC: } \\
\text { induced IL-6 and IL-12 release } \\
\text { and up-regulation of CD86 }\end{array}$ & [44] \\
$\beta$-gal, EGFP, or CMV pp65 & Human PBMC & $\begin{array}{c}\text { Complexes induced release of } \\
\text { strong IL-6 and TNF- } \alpha, \\
\text { stimulation of innate } \\
\text { immunity and other APCs }\end{array}$ & [62] \\
\hline
\end{tabular}


Table 1. Cont.

\begin{tabular}{|c|c|c|c|}
\hline Target mRNA & Stage & Findings & Ref. \\
\hline $\begin{array}{c}\text { Melan-A, Tyrosinase, gp100, } \\
\text { MAGE-A1, MAGE-A3, and } \\
\text { Survivin }\end{array}$ & $\begin{array}{l}\text { Individuals with metastatic } \\
\text { melanoma }\end{array}$ & $\begin{array}{c}\text { Raised frequency of } \\
\text { immunosuppressive and } \\
\text { vaccine-directed cellular } \\
\text { immune response }\end{array}$ & [28] \\
\hline $\begin{array}{c}\text { OVA (GgOVA), control } \\
\text { vaccine (Ec } \beta \text {-gal sh), PSMA } \\
\text { (HsPSMA), and STEAP } \\
\text { vaccine (HsSTEAP) }\end{array}$ & Rat (C57BL/6, BALB/c) & $\begin{array}{l}\text { Showed antitumor by } \\
\text { activating adaptive and innate } \\
\text { immune systems, stimulation } \\
\text { of toll-like receptor } 7 \text { (TLR-7), } \\
\text { ability to inhibit established } \\
\text { tumors, induction of two } \\
\text { component mRNA vaccine }\end{array}$ & {$[64]$} \\
\hline $\begin{array}{l}\text { Ovalbumin with radiation, } \\
\text { two component vaccine }\end{array}$ & Rat (C57BL/6) & $\begin{array}{l}\text { mRNA immunotherapy and } \\
\text { tumor irradiation act } \\
\text { synergistically to eradicate } \\
\text { established tumor (Lewis } \\
\text { lung cancer) }\end{array}$ & [69] \\
\hline Rabies glycoprotein (RABV-G) & $\begin{array}{c}\text { Rat (C57BL/6, BALB/c) and } \\
\text { domestic pigs }\end{array}$ & $\begin{array}{l}\text { Induced potent neutralizing } \\
\text { antibody superior to licensed } \\
\text { vaccines, induced lethal } \\
\text { challenge against rabies, } \\
\text { induce homeostasis }\end{array}$ & {$[68]$} \\
\hline $\begin{array}{l}\text { RNActive Ovalbumin, } \\
\text { luciferase fused rabies } \\
\text { glycoprotein, two } \\
\text { component vaccine }\end{array}$ & Rat (C57BL/6, BALB/c) & $\begin{array}{l}\text { Vaccine taken up by leukocyte } \\
\text { and non-leukocytic cells, } \\
\text { represented by APCs, } \\
\text { transport to draining lymph } \\
\text { nodes (dLNs), T-cell } \\
\text { proliferation, immune cell } \\
\text { activations, and induction of } \\
\text { adaptive immunity }\end{array}$ & [70] \\
\hline
\end{tabular}

\subsection{Lipid Nanoparticles}

The area of lipid nanoparticles-based vaccination is comparatively advanced than other methodologies. Until now, various lipid-based formulations have been investigated for their efficiency in mRNA delivery. Among these, cationic lipids are widely administered due to their promising electrostatic interactions with anionic mRNA to form nanobiomaterial. LNPs show many advantages over other vectors, such as (a) the synthesis of LNP is robust, where both constituents and composition can easily be changed to improve delivery efficacy with lower toxicity, (b) LNPs have been effectively used earlier as delivery vehicles for mRNA-based vaccines, and (c) immune potentiators, including adjuvants or immune cell directing ligands, can be included to modify the immune response $[57,71-73]$. This field was pioneered in 1989 by Malone et al. while DOTMA (N-[1-(2,3-dioleyloxy)propyl]-N,N,N-trimethylammonium chloride) was used to transfect human, drosophila, rat, Xenopus (frog), and mouse cells with mRNA encoding luciferase [74]. However, the clinical progress of such lipid-based tools has been troubled by their toxicity [74]. Despite these limitations, DOTMA together with DOTAP (1,2-dioleoyloxy-3-trimethyl ammonium propane chloride) showed a promising candidate for this purpose [75]. Moreover, although cationic LNPs can be efficient in vitro; however, in vivo effects are not much satisfactory because positively charged liposomes can readily be removed by the mononuclear phagocytosis.

The overlay of poly-ethylene-glycol (PEG) on lipid carriers has been applied extensively as delivery vehicles for nucleic acid payloads, including DNA [76] and siRNA [77] to develop formulation method, decrease aggregation, and increase the time of blood circulation [78-80]. However, the PEGylation layer has also been exhibited to decline cellular uptake, an outcome that might be reduced by optimizing the content and size of 
PEG $[76,81,82]$. PEGylation has also been used for the delivery of nanoparticle-formulated mRNA, especially for lipid-polymer hybrid- and polymer nanoparticles $[83,84]$. The use of PEG modification to LNPs-based mRNA delivery systems for the development of their in vivo efficiency remains elusive. Incorporation of 1,2-dioleoyl-sn-glycero-3phosphoethanolamine (DOPE), a well-known helper lipid, is another approach to decrease accumulation of the lipid systems and to develop endosomal release (Figure 3) [85-87]. Akaike et al. [88] developed an alternative approach to further improve mRNA transfection efficiency in both non-mitotic and mitotic cells, by coating inorganic carbonate apatite nanoparticles on liposomal transporters. These inorganic apatite nanoparticles were shown to improve mRNA uptake via efficient endocytosis. They further reported that coating mRNA-containing DOTAP-apatite nanoparticles with arginyl-glycyl-aspartic acid, which is identified for its capacity to complex with integrins [89], increased cytoplasmic expression of transported mRNA. Owing to its potency for targeting as well as effective delivery of mRNA, this method seems to be versatile and bears huge potential $[75,88,90,91]$. Very recently, a new lipid/protamine/mRNA nanoparticle system was planned and broadly applied for systemic delivery to tumors [31]. DOTAP liposomes have been explored in this system to encapsulate protamine-complexed mRNA and later coated with DSPE-PEG and DSPE-PEG-anisamide [31]. This platform showed good stability from degradation in serum, elevated in vitro transfection efficiency in NCI-H460 cells, very low cytotoxicity, deposition in in vivo tumor site as well as anticancer activity [31].

Until now, LNPs have been extensively applied, predominantly to pioneer mRNA to induce immune cells for vaccine purposes. CureVac formulated mRNA with several sizes of $(70 \sim 100 \mathrm{~nm})$ lipid nanoparticles prepared by ionizable amino lipid, phospholipid, cholesterol, and PEGylated lipid. The developed vaccine was shown to be well-tolerated in NHPs (non-human primates), including mice and pigs, and elicited long-lasting humoral immune responses, which correlated with the protection against influenza and rabies infection. Remarkably, the cellular and humoral immunity in NHPs, mediated by LNP/mRNA vaccines, against influenza H3N2 and rabies viruses were superior over licensed Rabipur and Fluad vaccines, respectively [92]. The copious research conducted by CureVac (Thress et al.) using three different Epo (erythropoietin) sequences engineered, but chemically unmodified nucleoside mRNA formulated in LNPs (ionizable cationic lipid/phosphatidylcholine/cholesterol/-PEG; 50:10:38.5:1.5 mol/mol) [22]. The Epo mRNA vaccine resulted in significant physiological responses in mice and NHPs. Even in about $20 \mathrm{~kg}$ weight pigs, a single sufficient dose of engineered mRNA formulated in LNPs produced high systemic Epo levels and solid physiological outcomes.

Bahl et al. [93] formulated two H7N9 HA and H10N8 HA mRNA vaccines of influenza A in lipid nanoparticles (ionizable lipid: 1,2-dis-tearoyl-sn-glycero-3-phosphocholine: PEG: cholesterol) at 50:10:1.5:38.5 molar ratios. In this study, it was shown that LNPs complexed-modified mRNA encoding HA of H10N8 (A/Jiangxi Donghu/346/2013) or H7N9 (A/Anhui/1/2013) elicited quick and strong immune responses in ferrets, mice, and NHPs, as demonstrated by microneutralization and hemagglutination inhibition assays. Notably, a single dose of mRNA encoding H7N9 HA protected mice against the lethal challenge and lessened lung viral titers in ferrets. Results from an escalating-dose of phase 1 H10N8 HA trial first-in-human, exhibited very high rates of seroconversion, indicating a robust prophylactic immune response. Mild or moderate adverse effects were observed with no serious or only a few severe events. These data demonstrated that LNPcomplexed modified mRNA can introduce adaptive immunogenicity with a satisfactory tolerability profile.

In a separate study, a single dose of LNP-mRNA was demonstrated to induce rapid, robust, and long-time immunity in vivo; hence, facilitating both therapeutic and prophylactic challenge from lethal rabies intoxication or botulinum infection. Besides, therapeutic mRNA-induced antibody expression helped mice to survive against a lethal tumor [94]. A comparative analysis between pseudouridine-modified and unmodified mRNA-formulated C12-200 LNPs was performed in the in vivo mice model by Kauffman 
et al. [60]. Pseudouridine-modified mRNA showed no substantial benefit on physical properties of lipid nanoparticle, in the in vivo protein expression, or mRNA immunogenicity over unmodified mRNA while inoculated systemically with liver-directing LNPs, but decreased in vitro transfection efficiency. This report gives an insight into LNPs/modifiedmRNA mediated immune responses and advocates that pseudouridine modifications might not be essential for LNPs/mRNA-based therapeutics in liver disease.

Anderson et al. [57] reported a library to develop optimal lipid nanoparticle composition by varying the formulation parameters (Table 1 of [57]). The efficiency of the clinical trial was examined in an aggressive model of B16F10 melanoma. The analysis demonstrated a robust $\mathrm{CD} 8^{+} \mathrm{T}$ cell stimulation after a prime vaccination induced by the optimal composition of LNPs/mRNA. Treatment of B16F10 melanoma with LNPs complexed mRNA encoding for TRP2 and TAAs gp100 resulted in tumor fall and prolonged the overall endurance of the treated mice. The report also demonstrated increased immune response by the incorporation of lipopolysaccharide, a well-known adjuvant.

The Anderson group further established a combinatorial library using ionizable lipidlike materials to act as mRNA delivery vehicles, which accelerate the in vivo mRNA delivery and induce strong and explicit immune activation. Using a 3D multi-component model system, over 1000 lipid structures were synthesized and evaluated for their potency. The top formulations lipid candidates elicited a strong immune response and were shown to reduce tumor progression and increase survival in human papillomavirus E7 and melanoma. These lipid candidates share a corporate structure, such as, an unsaturated lipid tail, a dihydroimidazole linker, and cyclic amine head groups (Figure 3). Such formulations of lipid nanoparticles stimulated APCs maturation through the intracellular stimulator of interferon genes (STING) pathway, rather than via TLRs, and resulted in lower expression of systemic cytokine and improved anti-tumor efficacy [95].

A comprehensive overview of existing LNPs-based mRNA deliveries has been presented in various contemporary analyses [96-101], and a summary of these novel innovations has been shown in Table 2. Since the LNPs demonstrate a more comprehensively used system, their further improvement and optimization might open up a new door for the invention of more efficient mRNA delivery platforms.

Table 2. LNPs-mRNA formulated vaccination.

\begin{tabular}{|c|c|c|c|c|}
\hline Target mRNA & $\begin{array}{l}\text { Lipid Nanoparticle } \\
\text { Contents }\end{array}$ & Stage & Findings & Ref. \\
\hline Luciferase & $\begin{array}{l}\text { DOTAP liposomes } \\
\text { covered with apatite } \\
\text { nanoparticles }\end{array}$ & HeLa & $\begin{array}{l}\text { Along with ARCA had more } \\
\text { than } 100 \text {-fold increase } \\
\text { compared to DOTAP, } \\
\text { proportion not assessed }\end{array}$ & [91] \\
\hline Luciferase & $\begin{array}{l}\text { DOTAP liposomes } \\
\text { protected with apatite } \\
\text { nanoparticles }\end{array}$ & $\begin{array}{c}\text { HeLa } \\
\text { NIH 3T3 }\end{array}$ & $\begin{array}{l}\text { 9-14 fold improved compared } \\
\text { to mRNA liposome alone, } \\
\text { proportion not determined }\end{array}$ & [90] \\
\hline Luciferase & $\begin{array}{l}\text { Fibronectin associated } \\
\text { DOTAP liposomes } \\
\text { protected with apatite } \\
\text { nanoparticles }\end{array}$ & $\mathrm{HeLa}$ & $\begin{array}{c}\text { Fn-DOTAP-apatite complex } \\
\text { showed 50-fold increase than } \\
\text { DOTAP alone, proportion } \\
\text { not assessed }\end{array}$ & [75] \\
\hline $\begin{array}{l}\text { TriMix mRNA } \\
\text { encoding CD40-ligand, } \\
\text { CD70 and TLR }\end{array}$ & $\begin{array}{l}\text { DOTAP/DOPE/DSPE- } \\
\text { PEG-2000-biotin }\end{array}$ & $\begin{array}{l}\text { Primary murine bone } \\
\text { marrow-derived DC } \\
\text { from C57BL/ } 6 \text { mice }\end{array}$ & $19 \%$ improved & [102] \\
\hline Luciferase & $\begin{array}{l}\text { DOTAP/DOPE/DSPE- } \\
\text { PEG-2000-biotin } \\
\text { lipoplex loaded } \\
\text { microbubbles }\end{array}$ & $\begin{array}{l}\text { DC primary cultures } \\
\text { from the bone marrow } \\
\text { of C57BL } / 6 \text { mice }\end{array}$ & $24 \%$ improved & [103] \\
\hline
\end{tabular}


Table 2. Cont.

\begin{tabular}{|c|c|c|c|c|}
\hline Target mRNA & $\begin{array}{l}\text { Lipid Nanoparticle } \\
\text { Contents }\end{array}$ & Stage & Findings & Ref. \\
\hline EGFP & $\begin{array}{c}\text { Lipofectamine } 2000 \text { and } \\
\text { TransIT }\end{array}$ & $\begin{array}{c}\text { Neurospheres from } \\
\text { subventricular zone of } \\
\text { adult C57BL/6 mice }\end{array}$ & $40-50 \%$ improved & [104] \\
\hline GFP and luciferase & $\begin{array}{l}\text { MLRI/DOPE and } \\
\text { TransFast }\end{array}$ & $\mathrm{CHO}, \mathrm{NIH} 3 \mathrm{~T} 3$ & $\begin{array}{l}>50 \% \text { improved } \\
>40 \% \text { improved }\end{array}$ & [105] \\
\hline EGFP, B-16 & $\begin{array}{l}\text { Novel cationic lipids: } \\
\text { X2, S1, S2, S3, 2X3, and } \\
\text { 2D3 with DOPE }\end{array}$ & $\begin{array}{l}\text { DC cells cultured from } \\
\text { the bone marrow of } \\
\text { C57BL/6 mice }\end{array}$ & $\begin{array}{l}\text { Up to } 47 \% \text { of DC progenitors } \\
\text { Up to } 57 \% \text { of immature DCs }\end{array}$ & [106] \\
\hline $\begin{array}{l}\text { Herpes simplex virus } \\
\text { 1-thymidine kinase }\end{array}$ & $\begin{array}{l}\text { DOTAP-cholesterol } \\
\text { liposome with } \\
\text { DSPE-PEG and } \\
\text { DSPE-PEG-AA, } \\
\text { encapsulating } \\
\text { protamine-mRNA } \\
\text { cores }\end{array}$ & NCI-H460 xenograft & $68 \sim 78 \%$ improved & [31] \\
\hline $\begin{array}{l}\text { GFP, Luciferase and } \\
\text { CXCR4 }\end{array}$ & DOTAP/DOPE & $\mathrm{HeLa}$ & $\sim 80 \%$ improved & [107] \\
\hline Luciferase and GFP & Stemfect & JAWS II DC2.4 & $80 \% ;>97 \% ;>50 \%$ and $>60 \%$ & [108] \\
\hline $\begin{array}{l}\text { Photinus pyralis } \\
\text { luciferase (PpLuc), } \\
\text { rabies glycoprotein } \\
\text { (RABV-G), influenza }\end{array}$ & $\begin{array}{c}(70 \sim 100 \mathrm{~nm}) \text { lipid } \\
\text { nanoparticles prepared } \\
\text { by ionizable amino } \\
\text { lipid, PEGylated lipid, } \\
\text { phospholipid, and } \\
\text { cholesterol }\end{array}$ & $\mathrm{BALB} / \mathrm{c}$, pigs & $\begin{array}{c}\text { Lipid formulated mRNA } \\
\text { vaccine induced protective } \\
\text { antibody titers; boosted and } \\
\text { stable for } 1 \text { year }\end{array}$ & [92] \\
\hline $\begin{array}{l}\text { Photinus pyralis } \\
\text { luciferase (PpLuc), Epo } \\
\text { (mouse, pig } \\
\text { and maque) }\end{array}$ & $\begin{array}{c}\text { Inonizable cataionic } \\
\text { lipid/ } \\
\text { phosphatidylcholine/ } \\
\text { cholesterol/PEG; } \\
\text { 50:10:38.5:1.5 } \mathrm{mol} / \mathrm{mol}\end{array}$ & $\begin{array}{l}\text { HeLa, BALB/c, pigs, } \\
\text { monkeys }\end{array}$ & $\begin{array}{l}\text { Induced high mRNA } \\
\text { expression and elicited } \\
\text { significant physiological } \\
\text { response in mice and } \\
\text { nonhuman primates }\end{array}$ & [22] \\
\hline $\begin{array}{c}\text { mRNA encoding } \\
\text { hemagglutinin of } \\
\text { H10N8 (A/Jiangxi- } \\
\text { Donghu-/346/2013) or } \\
\text { H7N9 } \\
\text { (A/Anhui/1/2013) } \\
\text { influenza virus }\end{array}$ & $\begin{array}{l}\text { Ionizable lipid: } 1,2- \\
\text { distearoyl-sn-glycero-3- } \\
\text { phosphocholine } \\
\text { (DSPC): cholesterol: } \\
\text { PEG-lipid } \\
\text { (50:10:38.5:1.5) }\end{array}$ & $\begin{array}{c}\text { HeLa, BALB/c, ferrets, } \\
\text { cynomolgus monkeys, } \\
\text { human }\end{array}$ & $\begin{array}{l}\text { Induced rapid and robust } \\
\text { immune responses in ferrets, } \\
\text { mice, and NHPs; single dose of } \\
\text { mRNA encoding H7N9 saved } \\
\text { mice against lethal challenge } \\
\text { and decreased lung viral titers } \\
\text { in ferrets; elicited robust } \\
\text { immune response in humans } \\
\text { with mild or } \\
\text { moderate adversity }\end{array}$ & [93] \\
\hline $\begin{array}{l}\text { Luciferase, Ovalbumin } \\
\text { (OVA) expressing } \\
\text { B16F10 mouse } \\
\text { melanoma }\end{array}$ & $\begin{array}{l}\text { Lipid nanoparticles } \\
\text { library }\end{array}$ & C57BL/6J & $\begin{array}{l}\text { Optimized LNPs showed } \\
\text { transfection in various } \\
\text { immune cells; stimulation of a } \\
\text { robust CD8 }{ }^{+} \text {T-cell response } \\
\text { after single immunization; } \\
\text { greater survival rate in a } \\
\text { transgenic mice melanoma }\end{array}$ & [57] \\
\hline $\begin{array}{c}\text { Firefly luciferase, } \\
\text { Ovalbumin (OVA) } \\
\text { expressing B16F10 } \\
\text { mouse melanoma, } \\
\text { papilloma E7 protein }\end{array}$ & $\begin{array}{l}\text { Multi-dimensional over } \\
1000 \text { lipid nanoparticles } \\
\text { consisting of } \\
\text { heterocyclic ring }\end{array}$ & $\begin{array}{c}\text { HeLa, bone } \\
\text { marrow-derived } \\
\text { dendritic cells and bone } \\
\text { marrow-derived and } \\
\text { peritoneal } \\
\text { macrophages, Ai14 } \\
\text { mice model }\end{array}$ & $\begin{array}{l}\text { Top-performing lipid elicited a } \\
\text { robust immune activation, } \\
\text { prevented tumor progression } \\
\text { and long-lasting survival in } \\
\text { human papillomavirus E7 and } \\
\text { melanoma in the in vivo } \\
\text { tumor model }\end{array}$ & [95] \\
\hline
\end{tabular}




\subsection{Electroporation Plus Nanoparticles Formulation}

Cell-specific mRNA delivery (electroporation) represents an alternative approach for the expansion of mRNA vaccines. This can increase mRNA delivery to the target cells and thus decrease necessary mRNA dose by decreasing possible off-target effects. The cell-specific mRNA delivery works on the principle of professional APCs (e.g., dendritic cells) being in the vicinity of T-lymphocytes in these cell organs, therefore, offering optimal environments for effective priming as well as increasing T-cell stimulations in vivo (Figure 4) [71,109]. However, previous observations have shown that DCs have been only and weakly transfected by lipoplexes [100]. Hence, nanoparticle formulations were needed to optimize for improved targeting of dendritic cells [84].

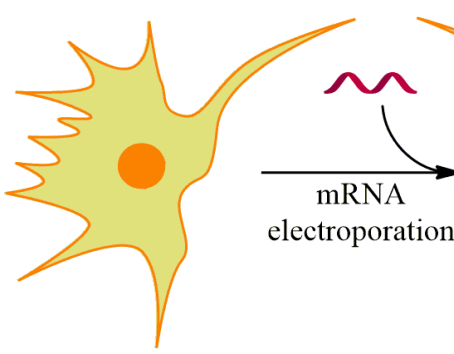

Dendritic cell

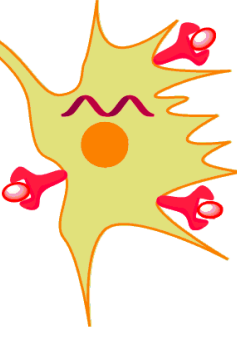

Antigen-presenting dendritic cell

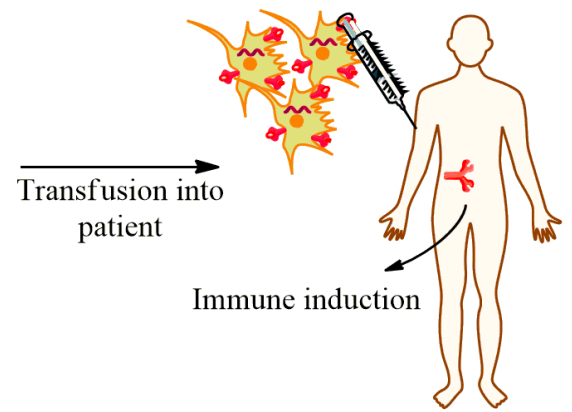

Figure 4. mRNA electroporation into the dendritic cell for vaccination process. mRNA transfection induces DC to present antigens, which then transfuse into the patient to establish immune defense.

The cell-specific delivery of IVT mRNA/nanoparticles through effective targeting has been reported to induce potent effector as well as memory T-lymphocytes responses, and strong IFN- $\alpha$-mediated eradication of advanced tumors. Associated with cancer immunotherapy, dendritic cells could be transfected with either total tumor RNA or tumor-associated antigens (TAAs) encoding mRNA [109]. DCs transfected with messenger RNA encoding tumor-associated antigens can be used directly for vaccination purposes without the demand of exploiting patient-specific tumor-derived cells or protein antigens $[13,110,111]$. The shortcomings of this method include the deficiency of known TAAs for various cancers and the choice of TAAs might be challenging since not all recognized TAAs induce antitumor immunity. Experimental analyses on TAA mRNAs were shown to prompt the induction of antitumor immunity [112]. For example, dendritic cells transfected with mRNA encoding prostate-specific antigen (PSA) TAAs induced potent PSA-specific T-cell responses in prostate cancer patients and elicited a substantial decline in PSA level in 6 out of 7 patients [24]. Furthermore, inoculation with CEA (carcinoembryonic antigen) mRNA transfected DCs revealed a well-tolerance in pancreatic cancer individuals while antitumor immunities were only achieved in 6 of 24 patients $[25,26]$. Besides, mannosylated-histidylated-lipopolyplex were loaded for improved mRNA transfection of dendritic cells [84]. Intravenous injection exhibited four-times lower DCs expressing EGFP for mRNA-loaded with sugar-free LPR100 compared with Man (11)-LPR100. The increased transfection of DCs associated with increased growth inhibition of B16F10 melanoma and prolonged survival period after vaccination with MART1 mRNA-formulated Man (11)-LPR100. The method of exploiting total tumor RNA from tumor-specific patients was also assessed in clinical trials for renal [113,114], lung [115], brain [116] cancers, and melanoma [117-119]. In this regard, clinical findings to neuroblastomas and brain tumors were witnessed in approximately a third of the total registered patients [116]. Additionally, analyses in individuals with renal cell carcinoma exhibited no indication of induced autoimmunity or dose-limiting toxicity [113] 


\section{Challenges and Safety Issues in the Development of mRNA-Based Vaccines against Novel Antigens}

The potential benefit of RNA-based therapeutics is their rapid development with lower side effects. The single-stranded IVT mRNA therapeutics are free from the hazard of genomic integration with the host cell and are efficient to generate high-quality viral protein. Besides, mRNAs are rapidly expressed and thus allowing the protein to be manufactured inside the cell. Experimental analyses of mRNA for rapid biological therapy has revealed outstanding tolerability as well as safety profile and reported that mRNAbased vaccines have no potential platform-inherent concerns [120]. However, for a majority of other mRNA-based therapeutic applications, such as protein replacement therapy, where preclinical and clinical trials are still very limited, researchers are unclear about the potential challenges and types of safety issues that should be considered [121]. Nevertheless, vaccine developers have pointed out several challenges and safety trials for developing novel vaccines against new infections e.g., SARS-CoV2.

Like other viruses, the novel coronavirus is an RNA virus, which exerts its effect via ' $\mathrm{S}$ ' protein consisting of 1273 amino acid residues. This virus showed high mutation efficacy and genetic instability that may hamper immune induction [122]. Therefore, it is vital to understand genetic changes in the coding as well as non-coding sequences, genetic variant, pathogenicity, and host-pathogen interrelations. Genetic alteration in the ' $S$ ' protein likely to stimulate its folding pattern, which may change antigenicity and, consequently, may disturb vaccine design [123-125]. Copious reports advocated that mutations in the target proteins may be interrelated with drug resistance, leading to vaccine inefficacy. Therefore, immunogen selection for the mRNA-based vaccine development should be carefully considered and designed.

It is also critical to focus that insecurity over long-durable protection still exists against COVID-19. In several reports, there is evidence of reinfections. In such cases, it is required to report how long a protective immune induction will be continued in a patient [126-128]. Regarding the immunogenicity of the COVID-19 mRNA therapeutic in elderly individuals, it has been demonstrated that after the second inoculation, serum neutralizing titer was noticed in all the populations. Surprisingly, the binding as well as antibody neutralizing efficiency was comparable to those stated among vaccine receivers from 18 to 55 years old and were over the average of a group of control populations [129].

In the present pandemic situation, several researchers advised that immune inductions against coronavirus can lead to ADE (antibody-dependent enhancement) [130,131]. Although it was reported that immunization of the COVID19 receptor-binding domain did not mediate ADE in rodents [132], this principle could contribute to the pathology of several feline coronaviruses and flavivirus [132], notably dengue virus [133]. Nevertheless, ADE should be taken into consideration while evolving therapeutics against novel viruses [134,135]. In addition, considering the emergency need for a COVID-19 vaccine worldwide, being over-precautions, the authority should not stop the release of safe, well-tolerated, and efficient vaccines to the general populations [135-137]. Some reports demonstrated the safety concern of vaccine-enhanced disorder for inactivated vaccine candidates, remarkably vaccine-associated enhanced respiratory disease (Table 3) [138-141].

Although mRNA vaccines can be manufactured with a minimum time; however, large-scale production of these therapeutics remains a challenging task owing to its huge uncertainty to meet the demand during the pandemic. Additionally, in recent years, nucleic acid-based vaccines could not produce effective platforms for human infections and other diseases using temperature-sensitive lipid nanoparticles, which may hamper for scaling up vaccine manufacture [138]. For example, BNT162b2 and the Pfizer-BioNTech COVID19 vaccines, are lipid nanoparticle-formulated nucleoside-modified mRNA vaccines that encode SARS-CoV-2 spike protein [121]. Following the issuance of the emergency use authorization (EUA) for the BNT162b2 vaccine by the U.S. Food and Drug Administration in December 2020, the vaccination scheme of this vaccine was launched later in the U.S and other countries. However, the plan for massive immunization has been delayed by 
the stringent requirement of storage and transportation of the BNT162b2 vaccine. Besides, cold chain transportation is not available in many COVID-19 epidemic areas, so potent mRNA vaccines with enhanced temperature stability will be highly preferred in the future. Despite huge challenges and risk factors involved in the development of mRNA-based vaccines in clinical trials, several mRNA-based vaccines in human trials have been reported in the literature that has been summarized in Table 3.

Table 3. mRNA-based vaccines in human clinical trials with their major finding and adversity.

\begin{tabular}{|c|c|c|c|c|}
\hline $\begin{array}{l}\text { Antigen/Study } \\
\text { Identifier/Phase }\end{array}$ & Subjects/Numbers & Route & Major Findings & Ref. \\
\hline $\begin{array}{c}\text { Rabies glycopro- } \\
\text { tein/NCT02241135/ } \\
\text { Phase I }\end{array}$ & $\begin{array}{l}\text { 18-40 years } \\
\text { (volunteers), } 101 \\
\text { healthy individuals }\end{array}$ & ID and IM & $\begin{array}{l}94 \% \text { of ID and } 97 \% \text { of IM vaccinated } \\
\text { populations received severe injection } \\
\text { site reactions, and } 78 \% \text { ID and } 78 \% \text { of } \\
\text { IM injected peoples demonstrated } \\
\text { severe systemic reactions, induce } \\
\text { antibody response when administered } \\
\text { with a needle free device, safe with a } \\
\text { tolerability profile }\end{array}$ & [142] \\
\hline $\begin{array}{l}\text { Melan-A, Tyrosinase, } \\
\text { gp100, MAGE-A1, } \\
\text { MAGE-A3, Sur- } \\
\text { vivin/NCT00204607/ } \\
\text { Phase I/II }\end{array}$ & $\begin{array}{l}18-80 \text { years, } 21 \text { patients } \\
\text { with metastatic } \\
\text { melanoma }\end{array}$ & ID & $\begin{array}{l}\text { No adversity was observed more than } \\
\text { grade II, feasible and safe, rate of } \\
\text { Foxp3+/CD4+ regulatory T } \\
\text { lymphocytes were reduced significantly } \\
\text { upon mRNA plus keyhole limpet } \\
\text { hemocyanin (KLH) injection, } \\
\text { CD11b+HLA-DR lo monocytes } \\
\text { (myeloid suppressor cells) were } \\
\text { decreased in the patients without } \\
\text { KLH addition }\end{array}$ & [28] \\
\hline $\begin{array}{l}\text { NY-ESO-1, MAGEC1, } \\
\text { MAGEC2, 5T4, } \\
\text { Survivin, } \\
\text { MUC1/NCT01915524/ } \\
\text { Phase 1b }\end{array}$ & $\begin{array}{l}\geq 18 \text { years, } 19 \text { patients } \\
\text { with NSCLC }\end{array}$ & ID & $\begin{array}{l}\text { No serious toxicity was observed, only } \\
7 \% \text { patients experienced grade }>3 \\
\text { related adversity, antigen-mediated } \\
\text { immune induction was seen in more } \\
\text { than } 2 / 3 \text { of patients }\end{array}$ & [143] \\
\hline $\begin{array}{l}\text { HIV-1/NCT00672191/ } \\
\text { Phase II }\end{array}$ & $\begin{array}{l}18 \text { to } 60 \text { years, } 59 \\
\text { participants }\end{array}$ & ID & $\begin{array}{l}\text { Develop immune control of } \\
\text { HIV-1 reproduction }\end{array}$ & [144] \\
\hline $\begin{array}{l}\text { Spike protein (COVID- } \\
\text { 19)/NCT04470427/ } \\
\text { Phase II }\end{array}$ & $\begin{array}{l}18 \text { to } 99 \text { years, } 30,000 \\
\text { participants }\end{array}$ & $\mathrm{IM}$ & Ongoing & [145] \\
\hline $\begin{array}{c}\text { Spike pro- } \\
\text { tein/NCT04283461/ } \\
\text { Phase I }\end{array}$ & $\begin{array}{l}56 \text { to } 70 \text { years, } \\
40 \text { healthy adults }\end{array}$ & $\mathrm{IM}$ & $\begin{array}{c}\text { Mild or moderate adversity was } \\
\text { observed, } 100 \mu \mathrm{g} \text { mRNA produced } \\
\text { higher virus neutralizing-antibody titers } \\
\text { than } 25 \mu \mathrm{g}\end{array}$ & [129] \\
\hline $\begin{array}{c}\text { Spike pro- } \\
\text { tein/NCT04368728/ } \\
\text { Phase I and II }\end{array}$ & 18 to 55 years, 45 adults & $\mathrm{IM}$ & $\begin{array}{l}\text { Adversity was dose-dependent, } \\
\text { transient, mostly mild to moderate }\end{array}$ & [146] \\
\hline $\begin{array}{c}\text { Spike pro- } \\
\text { tein/NCT04283461/ } \\
\text { Phase I }\end{array}$ & $\begin{array}{l}18 \text { to } 55 \text { years, } 45 \\
\text { healthy adults }\end{array}$ & $\mathrm{IM}$ & $\begin{array}{l}\text { This vaccine candidate induced immune } \\
\text { responses against COVID-19 in all } \\
\text { populations, and no trial-limiting safety } \\
\text { issues were detected }\end{array}$ & [147] \\
\hline $\begin{array}{c}\text { Spike pro- } \\
\text { tein/NCT04566276/ } \\
\text { Phase I and II }\end{array}$ & $\begin{array}{l}65 \text { to } 75 \text { years, } 600 \\
\text { healthy adults }\end{array}$ & $\mathrm{IM}$ & Ongoing & [148] \\
\hline $\begin{array}{c}\text { Spike pro- } \\
\text { tein/NCT04515147/ } \\
\text { Phase II }\end{array}$ & $\begin{array}{l}18 \text { to } 60 \text { years, } 691 \\
\text { participants }\end{array}$ & $\mathrm{IM}$ & Ongoing & \\
\hline
\end{tabular}




\section{Future Direction and Conclusions}

mRNA-based therapies are state-of-the-art and rapidly evolving fields in vaccine research to eradicate acquired and hereditary ailments. For a couple of years alone, several clinical and preclinical trials have been reported based on the efficacy of the mRNA vaccine platforms. While most of the early work in this field mainly focused on cancer, a number of contemporary research studies have discussed the efficacy and flexibility of mRNA to protect from lethal challenges of infectious pathogens, such as influenza virus, Zika virus, rabies virus, Ebola virus, T. gondii, and Streptococcus spp. and currently expect high demand to search mRNA-based vaccines against recently outbroken novel COVID$19[56,68,149,150]$. Though unmodified linear mRNA has potential clinical benefit, this field requires overcoming many challenges including the delivery concerns, target management, and short-time protein expression, all of which are major limitations and can be the critical drawbacks to expand this field for extensive clinical use [61]. The rapid developments in biomaterials and nanotechnology can notably assist to overcome these difficulties [61]. This review has receptively presented the advancement of mRNA structure with an improved translation and cutting-aged nanomaterials systems to increase the ability of systemic mRNA delivery. Although more improvements are required, it is promising to see that many mRNA-based vaccine approaches have already reached the clinical trial stage soon after their development [28,151-153]. Further experiments are still necessary to find a revolutionary model to improve mRNA stability against the cellular ribonuclease, such as mRNA circularization, and also to search for novel nanoparticles/biomaterials including gold nanoparticle with improved formulations, which can offer biocompatibility and high transfection efficiency, high selectivity and specificity, and efficient systemic in vivo delivery and long-durable gene expression. With the progression along with the proper design of nanomaterials/biomaterials, the mRNA-based vaccine approach will likely be of high demand in clinical uses for years.

Author Contributions: M.M.R., designed and wrote the manuscript, drew the figures and tables; N.Z., extensively edited the manuscript; J.H., designed and edited the manuscript. This work was carried out in collaboration with all authors. All authors have read and agreed to the published version of the manuscript.

Funding: The work was supported by Shenzhen Peacock project (KQTD2015033-117210153), Shenzhen Science and Technology Innovation Committee Basic Science Research Grant (JCYJ20150629151046896), the Health and Medical Research Fund (COVID190117) to J.H. and National Natural Science Foundation of China (32001040) to N.Z. J.H. is supported by the L \& T Charitable Foundation.The funders had no role in the design of the study.

Acknowledgments: The work was supported by Shenzhen Peacock project (KQTD2015033-117210153), Shenzhen Science and Technology Innovation Committee Basic Science Research Grant (JCYJ20150629151046896), National Natural Science Foundation of China (32001040). J.H. is supported by L \& T Charitable Foundation and the program for Guangdong Introducing Innovative and Entrepreneurial Teams (2019BT02Y198).

Conflicts of Interest: The authors declare no conflict of interest.

\section{References}

1. Pardi, N.; Hogan, M.J.; Porter, F.W.; Weissman, D. mRNA vaccines-a new era in vaccinology. Nat. Rev. Drug Discov. 2018, 17, 261-279. [CrossRef]

2. Younger, D.S.; Younger, A.P.J.; Guttmacher, S. Childhood Vaccination: Implications for Global and Domestic Public Health. Neurol. Clin. 2016, 34, 1035-1047. [CrossRef] [PubMed]

3. Plotkin, S.A. Vaccines: The fourth century. Clin. Vaccine Immunol. 2009, 16, 1709-1719. [CrossRef] [PubMed]

4. Rodrigues, C.M.C.; Pinto, M.V.; Sadarangani, M.; Plotkin, S.A. Whither vaccines? J. Infect. 2017. [CrossRef]

5. Wolff, J.A.; Malone, R.W.; Williams, P.; Chong, W.; Acsadi, G.; Jani, A.; Agnes, F.; Philip, L. Direct gene transfer into mouse muscle in vivo. Science (80-) 1990, 247, 1465-1468. [CrossRef] [PubMed]

6. Jirikowski, G.F.; Sanna, P.P.; Maciejewski-Lenoir, D.; Bloom, F.E. Reversal of diabetes insipidus in Brattleboro tats: Intrahypothalamic injection of vasopressin mRNA. Science (80-) 1992, 255, 996-998. [CrossRef] 
7. Suschak, J.J.; Williams, J.A.; Schmaljohn, C.S. Advancements in DNA vaccine vectors, non-mechanical delivery methods, and molecular adjuvants to increase immunogenicity. Hum. Vaccines Immunother. 2017, 13, 2837-2848. [CrossRef] [PubMed]

8. Schmidt, S.T.; Foged, C.; Korsholm, K.S.; Rades, T.; Christensen, D. Liposome-based adjuvants for subunit vaccines: Formulation strategies for subunit antigens and immunostimulators. Pharmaceutics 2016, 8, 1-22.

9. Sahin, U.; Karikó, K.; Türeci, Ö. mRNA-based therapeutics-developing a new class of drugs. Nat. Rev. Drug Discov. 2014, 13, 759-780. [CrossRef]

10. Zhong, Z.; Mc Cafferty, S.; Combes, F.; Huysmans, H.; De Temmerman, J.; Gitsels, A.; Arlieke, V.; Daisy, P.C.; João, S.; Niek, N. mRNA therapeutics deliver a hopeful message. Nano Today 2018, 23, 16-39. [CrossRef]

11. Martinon, F.; Krishnan, S.; Lenzen, G.; Magné, R.; Gomard, E.; Guillet, J.-G.; Lévy, J.P.; Meulien, P. Induction of virus-specific cytotoxic T lymphocytes in vivo by liposome-entrapped mRNA. Eur. J. Immunol. 1993, 23, 1719-1722. [CrossRef] [PubMed]

12. Conry, R.M.; LoBuglio, A.F.; Wright, M.; Sumerel, L.; Pike, M.J.; Johanning, F.; Benjamin, R.; Lu, D.; Curiel, D.T. Characterization of a Messenger RNA Polynucleotide Vaccine Vector. Cancer Res. 1995, 55, 1397-1400.

13. Boczkowski, D.; Nair, S.K.; Snyder, D.; Gilboa, E. Dendritic cells pulsed with RNA are potent antigen-presenting cells in vitro and in vivo. J. Exp. Med. 1996, 184, 465-472. [CrossRef]

14. Qiu, P.; Ziegelhoffer, P.; Sun, J.; Yang, N.S. Gene gun delivery of mRNA in situ results in efficient transgene expression and genetic immunization. Gene Ther. 1996, 3, 262-268. [PubMed]

15. Mandl, C.W.; Aberle, J.H.; Aberle, S.W.; Holzmann, H.; Allison, S.L.; Heinz, F.X. In vitro-synthesized infectious RNA as an attenuated live vaccine in a flavivirus model. Nat. Med. 1998, 4, 1438-1440. [CrossRef] [PubMed]

16. Zhou, W.Z.; Hoon, D.S.B.; Huang, S.K.S.; Fujii, S.; Hashimoto, K.; Morishita, R.; Kaneda, Y. RNA melanoma vaccine: Induction of antitumor immunity by human glycoprotein 100 mRNA immunization. Hum. Gene Ther. 1999, 10, 2719-2724. [CrossRef]

17. Hoerr, I.; Obst, R.; Rammensee, H.G.; Jung, G. In vivo application of RNA leads to induction of specific cytotoxic T lymphocytes and antibodies. Eur. J. Immunol. 2000, 30, 1-7. [CrossRef]

18. Koido, S.; Kashiwaba, M.; Chen, D.; Gendler, S.; Kufe, D.; Gong, J. Induction of Antitumor Immunity by Vaccination of Dendritic Cells Transfected with MUC1 RNA. J. Immunol. 2000, 165, 5713-5719. [CrossRef]

19. Karikó, K.; Muramatsu, H.; Welsh, F.A.; Ludwig, J.; Kato, H.; Akira, S.; Weissman, D. Incorporation of pseudouridine into mRNA yields superior nonimmunogenic vector with increased translational capacity and biological stability. Mol. Ther. 2008, 16, 1833-1840. [CrossRef]

20. Kauffman, K.J.; Webber, M.J.; Anderson, D.G. Materials for non-viral intracellular delivery of messenger RNA therapeutics. J. Control Release 2016, 240, 227-234. [CrossRef]

21. Guan, S.; Rosenecker, J. Nanotechnologies in delivery of mRNA therapeutics using nonviral vector-based delivery systems. Gene Ther. 2017, 24, 133-143. [CrossRef] [PubMed]

22. Thess, A.; Grund, S.; Mui, B.L.; Hope, M.J.; Baumhof, P.; Fotin-Mleczek, M.; Schlake, T. Sequence-engineered mRNA Without Chemical Nucleoside Modifications Enables an Effective Protein Therapy in Large Animals. Mol. Ther. 2015, 23, 1456-1464. [CrossRef] [PubMed]

23. Karikó, K.; Muramatsu, H.; Ludwig, J.; Weissman, D. Generating the optimal mRNA for therapy: HPLC purification eliminates immune activation and improves translation of nucleoside-modified, protein-encoding mRNA. Nucleic Acids Res. 2011, 39 , e142. [CrossRef] [PubMed]

24. Heiser, A.; Coleman, D.; Dannull, J.; Yancey, D.; Maurice, M.A.; Lallas, C.D.; Dahm, P.; Niedzwiecki, D.; Gilboa, E.; Vieweg, J. Autologous dendritic cells transfected with prostate-specific antigen RNA stimulate CTL responses against metastatic prostate tumors. J. Clin. Investig. 2002, 109, 409-417. [CrossRef] [PubMed]

25. Morse, M.A.; Nair, S.K.; Boczkowski, D.; Tyler, D.; Hurwitz, H.I.; Proia, A.; Clay, T.M.; Schlom, J.; Gilboa, E.; Lyerly, H.K. The feasibility and safety of immunotherapy with dendritic cells loaded with CEA mRNA following neoadjuvant chemoradiotherapy and resection of pancreatic cancer. Int. J. Gastrointest. Cancer 2002, 32, 1-6. [CrossRef]

26. Morse, M.A.; Nair, S.K.; Mosca, P.J.; Hobeika, A.C.; Clay, T.M.; Deng, Y.; Boczkowski, D.; Proia, A.; Neidzwiecki, D.; Clavien, P.A.; et al. Immunotherapy with autologous, human dendritic cells transfected with carcinoembryonic antigen mRNA. Cancer Investig. 2003, 21, 341-349. [CrossRef]

27. Su, Z.; Dannull, J.; Yang, B.K.; Dahm, P.; Coleman, D.; Yancey, D.; Sichi, S.; Niedzwiecki, D.; Boczkowski, D.; Gilboa, E.; et al. Telomerase mRNA-Transfected Dendritic Cells Stimulate Antigen-Specific CD8 + and CD4 + T Cell Responses in Patients with Metastatic Prostate Cancer. J. Immunol. 2005, 174, 3798-3807. [CrossRef]

28. Weide, B.; Pascolo, S.; Scheel, B.; Derhovanessian, E.; Pflugfelder, A.; Eigentler, T.K.; Pawelec, G.; Hoerr, I.; Rammensee, H.G.; Garbe, C. Direct injection of protamine-protected mRNA: Results of a phase 1/2 vaccination trial in metastatic melanoma patients. J. Immunother. 2009, 32, 498-507. [CrossRef]

29. Rittig, S.M.; Haentschel, M.; Weimer, K.J.; Heine, A.; Muller, M.R.; Brugger, W.; Horger, M.S.; Maksimovic, O.; Stenzl, A.; Hoerr, I.; et al. Intradermal vaccinations with RNA coding for TAA generate CD8 and CD4 immune responses and induce clinical benefit in vaccinated patients. Mol. Ther. 2011, 19, 990-999. [CrossRef]

30. Wilgenhof, S.; Van Nuffel, A.M.T.; Benteyn, D.; Corthals, J.; Aerts, C.; Heirman, C.; Van Riet, I.; Bonehill, A.; Thielemans, K.; Neyns, B. A phase IB study on intravenous synthetic mRNA electroporated dendritic cell immunotherapy in pretreated advanced melanoma patients. Ann. Oncol. 2013, 24, 2686-2693. [CrossRef] 
31. Wang, Y.; Su, H.H.; Yang, Y.; Hu, Y.; Zhang, L.; Blancafort, P.; Huang, L. Systemic delivery of modified mRNA encoding herpes simplex virus 1 thymidine kinase for targeted cancer gene therapy. Mol. Ther. 2013, 21, 358-367. [CrossRef]

32. Mitchell, D.A.; Karikari, I.; Cui, X.; Xie, W.; Schmittling, R.; Sampson, J.H. Selective modification of antigen-specific T cells by RNA electroporation. Hum. Gene Ther. 2008, 19, 511-521. [CrossRef]

33. Okumura, K.; Nakase, M.; Inui, M.; Nakamura, S.; Watanabe, Y.; Tagawa, T. Bax mRNA therapy using cationic liposomes for human malignant melanoma. J. Gene Med. 2008, 10, 910-917. [CrossRef]

34. Schirrmacher, V.; Förg, P.; Dalemans, W.; Chlichlia, K.; Zeng, Y.; Fournier, P.; Von Hoegen, P. Intra-pinna anti-tumor vaccination with self-replicating infectious RNA or with DNA encoding a model tumor antigen and a cytokine. Gene Ther. 2000, 7, $1137-1147$. [CrossRef] [PubMed]

35. Zimmermann, O.; Homann, J.M.; Bangert, A.; Müller, A.M.; Hristov, G.; Goeser, S.; Wiehe, J.M.; Zittrich, S.; Rottbauer, W.; Torzewski, J.; et al. Successful use of mRNA-nucleofection for overexpression of interleukin-10 in murine monocytes/macrophages for anti-inflammatory therapy in a murine model of autoimmune myocarditis. J. Am. Heart Assoc. 2012, 1, e003293. [CrossRef]

36. Zangi, L.; Lui, K.O.; Von Gise, A.; Ma, Q.; Ebina, W.; Ptaszek, L.M.; Später, D.; Xu, H.; Tabebordbar, M.; Gorbatov, R.; et al. Modified mRNA directs the fate of heart progenitor cells and induces vascular regeneration after myocardial infarction. Nat. Biotechnol. 2013, 31, 898-907. [CrossRef]

37. Creusot, R.J.; Chang, P.; Healey, D.G.; Tcherepanova, I.Y.; Nicolette, C.A.; Fathman, C.G. A short pulse of IL-4 delivered by dcs electroporated with modified mRNA can both prevent and treat autoimmune diabetes in NOD mice. Mol. Ther. 2010, 18, 2112-2120. [CrossRef] [PubMed]

38. Kormann, M.S.D.; Hasenpusch, G.; Aneja, M.K.; Nica, G.; Flemmer, A.W.; Herber-Jonat, S.; Huppmann, M.; Mays, L.E.; Illenyi, M.; Schams, A.; et al. Expression of therapeutic proteins after delivery of chemically modified mRNA in mice. Nat. Biotechnol. 2011, 29, 154-157. [CrossRef] [PubMed]

39. Karikó, K.; Muramatsu, H.; Keller, J.M.; Weissman, D. Increased erythropoiesis in mice injected with submicrogram quantities of pseudouridine-containing mRNA encoding erythropoietin. Mol. Ther. 2012, 20, 948-953. [CrossRef]

40. Mays, L.E.; Ammon-Treiber, S.; Mothes, B.; Alkhaled, M.; Rottenberger, J.; Müller-Hermelink, E.S.; Grimm, M.; Mezger, M.; Beer-Hammer, S.; Von Stebut, E.; et al. Modified Foxp3 mRNA protects against asthma through an IL-10-dependent mechanism. J. Clin. Investig. 2013, 123, 1216-1228. [CrossRef]

41. Levy, O.; Zhao, W.; Mortensen, L.J.; LeBlanc, S.; Tsang, K.; Fu, M.; Phillips, J.A.; Sagar, V.; Anandakumaran, P.; Ngai, J.; et al. mRNA-engineered mesenchymal stem cells for targeted delivery of interleukin-10 to sites of inflammation. Blood 2013, 122, e23-e32. [CrossRef] [PubMed]

42. Holtkamp, S.; Kreiter, S.; Selmi, A.; Simon, P.; Koslowski, M.; Huber, C.; Türeci, Ö.; Sahin, U. Modification of antigenencoding RNA increases stability, translational efficacy, and T-cell stimulatory capacity of dendritic cells. Blood 2006, 108, 4009-4017. [CrossRef]

43. Karikó, K.; Kuo, A.; Barnathan, E.S. Overexpression of urokinase receptor in mammalian cells following administration of the in vitro transcribed encoding mRNA. Gene Ther. 1999, 6, 1092-1100. [CrossRef] [PubMed]

44. Kallen, K.J.; Theß, A. A development that may evolve into a revolution in medicine: MRNA as the basis for novel, nucleotide-based vaccines and drugs. Ther. Adv. Vaccines 2014, 2, 10-31. [CrossRef] [PubMed]

45. Gustafsson, C.; Govindarajan, S.; Minshull, J. Codon bias and heterologous protein expression. Trends Biotechnol. 2004, 22, 346-353. [CrossRef]

46. Mauro, V.P.; Chappell, S.A. A critical analysis of codon optimization in human therapeutics. Trends Mol. Med. 2014, 20, 604-613. [CrossRef]

47. Kudla, G.; Lipinski, L.; Caffin, F.; Helwak, A.; Zylicz, M. High guanine and cytosine content increases mRNA levels in mammalian cells. PLoS Biol. 2006, 4, e180. [CrossRef]

48. Kudla, G.; Murray, A.W.; Tollervey, D.; Plotkin, J.B. Coding-sequence determinants of expression in escherichia coli. Science (80-) 2009, 324, 255-258. [CrossRef]

49. Buhr, F.; Jha, S.; Thommen, M.; Mittelstaet, J.; Kutz, F.; Schwalbe, H.; Rodnina, M.V.; Komar, A.A. Synonymous Codons Direct Cotranslational Folding toward Different Protein Conformations. Mol. Cell 2016, 61, 341-351. [CrossRef]

50. Yu, C.H.; Dang, Y.; Zhou, Z.; Wu, C.; Zhao, F.; Sachs, M.S.; Liu, Y. Codon Usage Influences the Local Rate of Translation Elongation to Regulate Co-translational Protein Folding. Mol. Cell 2015, 59, 744-754. [CrossRef]

51. Karikó, K.; Buckstein, M.; Ni, H.; Weissman, D. Suppression of RNA recognition by Toll-like receptors: The impact of nucleoside modification and the evolutionary origin of RNA. Immunity 2005, 23, 165-175. [CrossRef]

52. Hornung, V.; Ellegast, J.; Kim, S.; Brzózka, K.; Jung, A.; Kato, H.; Poeck, H.; Akira, S.; Conzelmann, K.K.; Schlee, M.; et al. 5'-Triphosphate RNA is the ligand for RIG-I. Science (80-) 2006, 314, 994-997. [CrossRef] [PubMed]

53. Alexopoulou, L.; Holt, A.C.; Medzhitov, R.; Flavell, R.A. Recognition of double-stranded RNA and activation of NF-kB by Toll-like receptor 3. Nature 2001, 413, 732-738. [CrossRef] [PubMed]

54. Diebold, S.S.; Kaisho, T.; Hemmi, H.; Akira, S.; Reis e Sousa, C. Innate Antiviral Responses by Means of TLR7-Mediated Recognition of Single-Stranded RNA. Science (80-) 2004, 303, 1529-1531. [CrossRef]

55. Heil, F.; Hemmi, H.; Hochrein, H.; Ampenberger, F.; Kirschning, C.; Akira, S.; Lipford, G.; Wagner, H.; Bauer, S. Species-Specific Recognition of Single-Stranded RNA via Till-like Receptor 7 and 8. Science (80-) 2004, 303, 1526-1529. [CrossRef] 
56. Richner, J.M.; Himansu, S.; Dowd, K.A.; Butler, S.L.; Salazar, V.; Fox, J.M.; Julander, J.G.; Tang, W.W.; Shresta, S.; Pierson, T.C.; et al. Modified mRNA Vaccines Protect against Zika Virus Infection. Cell 2017. [CrossRef]

57. Oberli, M.A.; Reichmuth, A.M.; Dorkin, J.R.; Mitchell, M.J.; Fenton, O.S.; Jaklenec, A.; Anderson, D.G.; Langer, R.; Blankschtein, D. Lipid Nanoparticle Assisted mRNA Delivery for Potent Cancer Immunotherapy. Nano Lett. 2017, 17, 1326-1335. [CrossRef] [PubMed]

58. Pardi, N.; Hogan, M.J.; Naradikian, M.S.; Parkhouse, K.; Cain, D.W.; Jones, L.; Moody, M.A.; Verkerke, H.P.; Myles, A.; Willis, E.; et al. Nucleoside-modified mRNA vaccines induce potent $\mathrm{T}$ follicular helper and germinal center B cell responses. J. Exp. Med. 2018, 215, 1571-1588. [CrossRef] [PubMed]

59. Meyer, M.; Huang, E.; Yuzhakov, O.; Ramanathan, P.; Ciaramella, G.; Bukreyev, A. Modified mRNA-Based Vaccines Elicit Robust Immune Responses and Protect Guinea Pigs from Ebola Virus Disease. J. Infect. Dis. 2018, 217, 451-455. [CrossRef]

60. Kauffman, K.J.; Mir, F.F.; Jhunjhunwala, S.; Kaczmarek, J.C.; Hurtado, J.E.; Yang, J.H.; Webber, M.J.; Kowalski, P.S.; Heartlein, M.W.; DeRosa, F.; et al. Efficacy and immunogenicity of unmodified and pseudouridine-modified mRNA delivered systemically with lipid nanoparticles in vivo. Biomaterials 2016, 109, 78-87. [CrossRef]

61. Islam, M.A.; Reesor, E.K.G.; Xu, Y.; Zope, H.R.; Zetter, B.R.; Shi, J. Biomaterials for mRNA delivery. Biomater. Sci. 2015, 109 , 78-87. [CrossRef] [PubMed]

62. Scheel, B.; Teufel, R.; Probst, J.; Carralot, J.P.; Geginat, J.; Radsak, M.; Jarrossay, D.; Wagner, H.; Jung, G.; Rammensee, H.G.; et al. Toll-like receptor-dependent activation of several human blood cell types by protamine-condensed mRNA. Eur. J. Immunol. 2005, 35, 1557-1566. [CrossRef]

63. Barroso da Silva, F.L.; Derreumaux, P.; Pasquali, S. Protein-RNA complexation driven by the charge regulation mechanism. Biochem. Biophys. Res. Commun. 2018, 498, 264-273. [CrossRef] [PubMed]

64. Fotin-Mleczek, M.; Duchardt, K.M.; Lorenz, C.; Pfeiffer, R.; Ojkić-Zrna, S.; Probst, J.; Kallen, K.J. Messenger RNA-based vaccines with dual activity induce balanced TLR-7 dependent adaptive immune responses and provide antitumor activity. J. Immunother. 2011, 34, 1-15. [CrossRef] [PubMed]

65. Kallen, K.-J.; Gnad-Vogt, U.; Scheel, B.; Rippin, G.; Stenzl, A. A phase I/IIa study of the mRNA-based cancer vaccine CV9103 prepared with the RNActive technology results in distinctly longer survival than predicted by the Halabi Nomogram which correlates with the induction of antigen-specific immune responses. J. Immunother. Cancer 2013, 1, 219. [CrossRef]

66. Brown, D.M.; Dilzer, A.M.; Meents, D.L.; Swain, S.L. CD4 T Cell-Mediated Protection from Lethal Influenza: Perforin and Antibody-Mediated Mechanisms Give a One-Two Punch. J. Immunol. 2006, 177, 2888-2898. [CrossRef]

67. Grohskopf, L.; Uyeki, T.; Bresee, J.; Cox, N.; Bridges, C. Prevention and control of influenza with vaccines: Recommendations of the Advisory Committee on Immunization Practices (ACIP), 2011. Am. J. Transplant. 2011, 59, 1-62. [CrossRef]

68. Schnee, M.; Vogel, A.B.; Voss, D.; Petsch, B.; Baumhof, P.; Kramps, T.; Stitz, L. An mRNA Vaccine Encoding Rabies Virus Glycoprotein Induces Protection against Lethal Infection in Mice and Correlates of Protection in Adult and Newborn Pigs. PLoS Negl. Trop. Dis. 2016, 10, e0004746. [CrossRef]

69. Fotin-Mleczek, M.; Zanzinger, K.; Heidenreich, R.; Lorenz, C.; Kowalczyk, A.; Kallen, K.J.; Huber, S.M. mRNA-based vaccines synergize with radiation therapy to eradicate established tumors. Radiat. Oncol. 2014, 9, 1-13. [CrossRef]

70. Kowalczyk, A.; Doener, F.; Zanzinger, K.; Noth, J.; Baumhof, P.; Fotin-Mleczek, M.; Heidenreich, R. Self-adjuvanted mRNA vaccines induce local innate immune responses that lead to a potent and boostable adaptive immunity. Vaccine 2016, 34, 3882-3893 [CrossRef] [PubMed]

71. Kranz, L.M.; Diken, M.; Haas, H.; Kreiter, S.; Loquai, C.; Reuter, K.C.; Meng, M.; Fritz, D.; Vascotto, F.; Hefesha, H.; et al. Systemic RNA delivery to dendritic cells exploits antiviral defence for cancer immunotherapy. Nature 2016, 534, 396-401. [CrossRef]

72. Reichmuth, A.M.; Oberli, M.A.; Jeklenec, A.; Langer, R.; Blankschtein, D. mRNA vaccine delivery using lipid nanoparticles. Ther. Deliv. 2016, 7, 319-334. [CrossRef]

73. Arya, S.; Lin, Q.; Zhou, N.; Gao, X.; Huang, J.D. Strong Immune Responses Induced by Direct Local Injections of Modified mRNA-Lipid Nanocomplexes. Mol. Ther. Nucleic Acids 2020, 19, 1098-1109. [CrossRef] [PubMed]

74. Malone, R.W.; Felgner, P.L.; Verma, I.M. Cationic liposome-mediated RNA transfection. Proc. Natl. Acad. Sci. USA 1989, 86, 6077-6081. [CrossRef] [PubMed]

75. Zohra, F.T.; Maitani, Y.; Akaike, T. mRNA delivery through fibronectin associated liposome-apatite particles: A new approach for enhanced mRNA transfection to mammalian cell. Biol. Pharm. Bull. 2012, 35, 111-115. [CrossRef] [PubMed]

76. Harvie, P.; Wong, F.M.P.; Bally, M.B. Use of poly(ethylene glycol)-lipid conjugates to regulate the surface attributes and transfection activity of lipid-DNA particles. J. Pharm. Sci. 2000, 89, 652-663. [CrossRef]

77. Bao, Y.; Jin, Y.; Chivukula, P.; Zhang, J.; Liu, Y.; Liu, J.; Clamme, J.P.; Mahato, R.I.; Ng, D.; Ying, W.; et al. Effect of PEGylation on biodistribution and gene silencing of siRNA/lipid nanoparticle complexes. Pharm. Res. 2013, 30, 342-351. [CrossRef]

78. Heyes, J.; Hall, K.; Tailor, V.; Lenz, R.; MacLachlan, I. Synthesis and characterization of novel poly(ethylene glycol)-lipid conjugates suitable for use in drug delivery. J. Control Release 2006, 112, 280-290. [CrossRef] [PubMed]

79. Torchilin, V.P. Recent advances with liposomes as pharmaceutical carriers. Nat. Rev. Drug Discov. 2005, 4, 145-160. [CrossRef] [PubMed]

80. Woodle, M.C. Controlling liposome blood clearance by surface-grafted polymers. Adv. Drug Deliv. Rev. 1998, 32, 139-152. [CrossRef] 
81. Hatakeyama, H.; Akita, H.; Kogure, K.; Oishi, M.; Nagasaki, Y.; Kihira, Y.; Ueno, M.; Kobayashi, H.; Kikuchi, H.; Harashima, H. Development of a novel systemic gene delivery system for cancer therapy with a tumor-specific cleavable PEG-lipid. Gene Ther. 2007, 14, 68-77. [CrossRef]

82. Song, L.Y.; Ahkong, Q.F.; Rong, Q.; Wang, Z.; Ansell, S.; Hope, M.J.; Mui, B. Characterization of the inhibitory effect of PEG-lipid conjugates on the intracellular delivery of plasmid and antisense DNA mediated by cationic lipid liposomes. Biochim. Biophys. Acta Biomembr. 2002, 1558, 1-13. [CrossRef]

83. Mockey, M.; Bourseau, E.; Chandrashekhar, V.; Chaudhuri, A.; Lafosse, S.; Le Cam, E.; Quesniaux, V.F.J.; Ryffel, B.; Pichon, C.; Midoux, P. mRNA-based cancer vaccine: Prevention of B16 melanoma progression and metastasis by systemic injection of MART1 mRNA histidylated lipopolyplexes. Cancer Gene Ther. 2007, 14, 802-814. [CrossRef] [PubMed]

84. Perche, F.; Benvegnu, T.; Berchel, M.; Lebegue, L.; Pichon, C.; Jaffrès, P.A.; Midoux, P. Enhancement of dendritic cells transfection in vivo and of vaccination against B16F10 melanoma with mannosylated histidylated lipopolyplexes loaded with tumor antigen messenger RNA. Nanomedicine Nanotechnology. Biol. Med. 2011, 7, 445-453. [CrossRef]

85. Wasungu, L.; Hoekstra, D. Cationic lipids, lipoplexes and intracellular delivery of genes. J. Control Release 2006, 116, 255-264. [CrossRef] [PubMed]

86. Hirsch-Lerner, D.; Zhang, M.; Eliyahu, H.; Ferrari, M.E.; Wheeler, C.J.; Barenholz, Y. Effect of "helper lipid" on lipoplex electrostatics. Biochim. Biophys. Acta Biomembr. 2005, 1714, 71-84. [CrossRef] [PubMed]

87. Wasungu, L.; Stuart, M.C.A.; Scarzello, M.; Engberts, J.B.F.N.; Hoekstra, D. Lipoplexes formed from sugar-based gemini surfactants undergo a lamellar-to-micellar phase transition at acidic $\mathrm{pH}$. Evidence for a non-inverted membrane-destabilizing hexagonal phase of lipoplexes. Biochim. Biophys. Acta Biomembr. 2006, 1758, 1677-1684. [CrossRef]

88. Zohra, F.T.; Chowdhury, E.H.; Akaike, T. High performance mRNA transfection through carbonate apatite-cationic liposome conjugates. Biomaterials 2009, 30, 4006-4013. [CrossRef]

89. D'Souza, S.E.; Ginsberg, M.H.; Plow, E.F. Arginyl-glycyl-aspartic acid (RGD): A cell adhesion motif. Trends Biochem. Sci. 1991, 16, 246-250. [CrossRef]

90. Zohra, F.T.; Chowdhury, E.H.; Nagaoka, M.; Akaike, T. Drastic effect of nanoapatite particles on liposome-mediated mRNA delivery to mammalian cells. Anal. Biochem. 2005, 345, 164-166. [CrossRef]

91. Zohra, F.T.; Chowdhury, E.H.; Tada, S.; Hoshiba, T.; Akaike, T. Effective delivery with enhanced translational activity synergistically accelerates mRNA-based transfection. Biochem. Biophys. Res. Commun. 2007, 358, 373-378. [CrossRef]

92. Lutz, J.; Lazzaro, S.; Habbeddine, M.; Schmidt, K.E.; Baumhof, P.; Mui, B.L.; Tam, Y.K.; Madden, T.D.; Hope, M.J.; Heidenreich, R.; et al. Unmodified mRNA in LNPs constitutes a competitive technology for prophylactic vaccines. NPJ Vaccines 2017, 2, 29. [CrossRef]

93. Bahl, K.; Senn, J.J.; Yuzhakov, O.; Bulychev, A.; Brito, L.A.; Hassett, K.J.; Laska, M.E.; Smith, M.; Almarsson, Ö.; Thompson, J.; et al. Preclinical and Clinical Demonstration of Immunogenicity by mRNA Vaccines against H10N8 and H7N9 Influenza Viruses. Mol. Ther. 2017, 25, 1316-1327. [CrossRef]

94. Thran, M.; Mukherjee, J.; Pönisch, M.; Fiedler, K.; Thess, A.; Mui, B.L.; Hope, M.J.; Tam, Y.K.; Horscroft, N.; Heidenreich, R.; et al. mRNA mediates passive vaccination against infectious agents, toxins, and tumors. EMBO Mol. Med. 2017, 9, 1434-1447. [CrossRef]

95. Miao, L.; Li, L.; Huang, Y.; Delcassian, D.; Chahal, J.; Han, J.; Shi, Y.; Sadtler, K.; Gao, W.; Lin, J.; et al. Delivery of mRNA vaccines with heterocyclic lipids increases anti-tumor efficacy by STING-mediated immune cell activation. Nat. Biotechnol. 2019, 37, 1174-1185. [CrossRef]

96. Deering, R.P.; Kommareddy, S.; Ulmer, J.B.; Brito, L.A.; Geall, A.J. Nucleic acid vaccines: Prospects for non-viral delivery of mRNA vaccines. Expert Opin. Drug Deliv. 2014, 11, 885-899. [CrossRef]

97. Tavernier, G.; Andries, O.; Demeester, J.; Sanders, N.N.; De Smedt, S.C.; Rejman, J. mRNA as gene therapeutic: How to control protein expression. J. Control Release 2011, 150, 238-247. [CrossRef] [PubMed]

98. Midoux, P.; Pichon, C. Lipid-based mRNA vaccine delivery systems. Expert Rev. Vaccines 2014, 14, 221-234. [CrossRef] [PubMed]

99. Schwendener, R.A. Liposomes as vaccine delivery systems: A review of the recent advances. Ther. Adv. Vaccines 2014, 2, 159-182. [CrossRef]

100. Phua, K.K.L.; Nair, S.K.; Leong, K.W. Messenger RNA (mRNA) nanoparticle tumour vaccination. Nanoscale 2014, 6, 7715-7729. [CrossRef] [PubMed]

101. Feldman, R.A.; Fuhr, R.; Smolenov, I.; (Mick)Ribeiro, A.; Panther, L.; Watson, M.; Senn, J.J.; Smith, M.; Almarsson, Ö.; Pujar, H.S.; et al. mRNA vaccines against $\mathrm{H} 10 \mathrm{~N} 8$ and H7N9 influenza viruses of pandemic potential are immunogenic and well tolerated in healthy adults in phase 1 randomized clinical trials. Vaccine 2019, 37, 3326-3334. [CrossRef]

102. Dewitte, H.; Van Lint, S.; Heirman, C.; Thielemans, K.; De Smedt, S.C.; Breckpot, K.; Lentacker, I. The potential of antigen and TriMix sonoporation using mRNA-loaded microbubbles for ultrasound-triggered cancer immunotherapy. J. Control Release 2014, 194, 28-36. [CrossRef]

103. De Temmerman, M.L.; Dewitte, H.; Vandenbroucke, R.E.; Lucas, B.; Libert, C.; Demeester, J.; De Smedt, S.C.; Lentacker, I.; Rejman, J. mRNA-Lipoplex loaded microbubble contrast agents for ultrasound-assisted transfection of dendritic cells. Biomaterials 2011, 32, 9128-9135. [CrossRef]

104. McLenachan, S.; Zhang, D.; Palomo, A.B.A.; Edel, M.J.; Chen, F.K. mRNA transfection of mouse and human neural stem cell cultures. PLoS ONE 2013, 8, e83596. [CrossRef] 
105. Zou, S.; Scarfo, K.; Nantz, M.H.; Hecker, J.G. Lipid-mediated delivery of RNA is more efficient than delivery of DNA in non-dividing cells. Int. J. Pharm. 2010, 389, 232-243. [CrossRef] [PubMed]

106. Markov, O.O.; Mironova, N.L.; Maslov, M.A.; Petukhov, I.A.; Morozova, N.G.; Vlassov, V.V.; Zenkova, M.A. Novel cationic liposomes provide highly efficient delivery of DNA and RNA into dendritic cell progenitors and their immature offsets. J. Control Release 2012, 160, 200-210. [CrossRef] [PubMed]

107. Rejman, J.; Tavernier, G.; Bavarsad, N.; Demeester, J.; De Smedt, S.C. mRNA transfection of cervical carcinoma and mesenchymal stem cells mediated by cationic carriers. J. Control Release 2010, 147, 385-391. [CrossRef] [PubMed]

108. Phua, K.K.L.; Leong, K.W.; Nair, S.K. Transfection efficiency and transgene expression kinetics of mRNA delivered in naked and nanoparticle format. J. Control. Release 2013, 166, 227-233. [CrossRef]

109. McNamara, M.A.; Nair, S.K.; Holl, E.K. RNA-Based Vaccines in Cancer Immunotherapy. J. Immunol. Res. 2015, 2015, 9. [CrossRef]

110. Nair, S.K.; Hull, S.; Coleman, D.; Gilboa, E.; Lyerly, H.K.; Morse, M.A. Induction of carcinoembryonic antigen (CEA)-specific cytotoxic T-lymphocyte responses in vitro using autologous dendritic cells loaded with CEA peptide or CEA RNA in patients with metastatic malignancies expressing CEA. Int. J. Cancer 1999, 82, 121-124. [CrossRef]

111. Ponsaerts, P.; Van Tendeloo, V.F.I.; Berneman, Z.N. Cancer immunotherapy using RNA-loaded dendritic cells. Clin. Exp. Immunol. 2003, 134, 378-384. [CrossRef] [PubMed]

112. Nencioni, A.; Grünebach, F.; Schmidt, S.M.; Müller, M.R.; Boy, D.; Patrone, F.; Ballestrero, A.; Brossart, P. The use of dendritic cells in cancer immunotherapy. Crit. Rev. Oncol. Hematol. 2008, 15, 138-147. [CrossRef]

113. Su, Z.; Dannull, J.; Heiser, A.; Yancey, D.; Pruitt, S.; Madden, J.; Coleman, D.; Niedzwiecki, D.; Gilboa, E.; Vieweg, J. Immunological and clinical responses in metastatic renal cancer patients vaccinated with tumor RNA-transfected dendritic cells. Cancer Res. 2003, 63, 2127-2133.

114. Dannull, J.; Su, Z.; Rizzieri, D.; Yang, B.K.; Coleman, D.; Yancey, D.; Zhang, A.; Dahm, P.; Chao, N.; Gilboa, E.; et al. Enhancement of vaccine-mediated antitumor immunity in cancer patients after depletion of regulatory T cells. J. Clin. Investig. 2005, 115, 3623-3633. [CrossRef] [PubMed]

115. Nair, S.K.; Morse, M.; Boczkowski, D.; Ian Cumming, R.; Vasovic, L.; Gilboa, E.; Kim Lyerly, H. Induction of tumor-specific cytotoxic T lymphocytes in cancer patients by autologous tumor RNA-transfected dendritic cells. Ann. Surg. 2002, 235, 540-549. [CrossRef] [PubMed]

116. Caruso, D.A.; Orme, L.M.; Neale, A.M.; Radcliff, F.J.; Amor, G.M.; Maixner, W.; Downie, P.; Hassall, T.E.; Tang, M.L.K.; Ashley, D. Results of a phase 1 study utilizing monocyte-derived dendritic cells pulsed with tumor RNA in children and young adults with brain cancer. Neuro Oncol. 2004. [CrossRef] [PubMed]

117. Bonehill, A.; Van Nuffel, A.M.T.; Corthals, J.; Tuyaerts, S.; Heirman, C.; François, V.; Colau, D.; Van Der Bruggen, P.; Neyns, B.; Thielemans, K. Single-step antigen loading and activation of dendritic cells by mRNA electroporation for the purpose of therapeutic vaccination in melanoma patients. Clin. Cancer Res. 2009, 15, 3366-3375. [CrossRef] [PubMed]

118. Kyte, J.A.; Kvalheim, G.; Aamdal, S.; Sæbøe-Larssen, S.; Gaudernack, G. Preclinical full-scale evaluation of dendritic cells transfected with autologous tumor-mRNA for melanoma vaccination. Cancer Gene Ther. 2005, 12, 579-591. [CrossRef] [PubMed]

119. Schuurhuis, D.H.; Verdijk, P.; Schreibelt, G.; Schreibelt, E.H.J.G.; Scharenborg, N.; De Boer, A.; Van de Rakt, M.W.M.M.; Kerkhoff, M.; Gerritsen, M.J.P.; Eijckeler, F.; et al. In situ expression of tumor antigens by messenger RNA-electroporated dendritic cells in lymph nodes of melanoma patients. Cancer Res. 2009, 69, 2927-2934. [CrossRef]

120. Wadhwa, A.; Aljabbari, A.; Lokras, A.; Foged, C.; Thakur, A. Opportunities and challenges in the delivery of mrna-based vaccines. Pharmaceutics 2020, 12, 102. [CrossRef]

121. Polack, F.P.; Thomas, S.J.; Kitchin, N.; Absalon, J.; Gurtman, A.; Lockhart, S.; Perez, J.L.; Pérez Marc, G.; Moreira, E.D.; Zerbini, C.; et al. Safety and Efficacy of the BNT162b2 mRNA Covid-19 Vaccine. N. Engl. J. Med. 2020, 38, 2603-2615. [CrossRef]

122. Silveira, M.M.; Moreira, G.M.S.G.; Mendonça, M. DNA vaccines against COVID-19: Perspectives and challenges. Life Sci. 2021, 267, 118921. [CrossRef] [PubMed]

123. Deng, X.; StJohn, S.E.; Osswald, H.L.; O’Brien, A.; Banach, B.S.; Sleeman, K.; Ghosh, A.K.; Mesecar, A.D.; Baker, S.C. Coronaviruses Resistant to a 3C-Like Protease Inhibitor Are Attenuated for Replication and Pathogenesis, Revealing a Low Genetic Barrier but High Fitness Cost of Resistance. J. Virol. 2014, 84, 11886-11898. [CrossRef] [PubMed]

124. Wang, X.W.; Li, J.S.; Jin, M.; Zhen, B.; Kong, Q.X.; Song, N.; Xiao, W.J.; Yin, J.; Wei, W.; Wang, G.J.; et al. Study on the resistance of severe acute respiratory syndrome-associated coronavirus. J. Virol. Methods 2005, 126, 171-177. [CrossRef]

125. Naqvi, A.A.T.; Fatima, K.; Mohammad, T.; Fatima, U.; Singh, I.K.; Singh, A.; Atif, S.M.; Hariprasad, G.; Hasan, G.M.; Hassan, M.I. Insights into SARS-CoV-2 genome, structure, evolution, pathogenesis and therapies: Structural genomics approach. Biochim. Biophys. Acta Mol. Basis Dis. 2020, 1866, 165878. [CrossRef]

126. Roy, S. COVID-19 Reinfection: Myth or Truth? SN Compr. Clin. Med. 2020, 2, 710-713. [CrossRef]

127. Alizargar, J. Risk of reactivation or reinfection of novel coronavirus (COVID-19). J Formos. Med. Assoc. 2020, 119, 1123. [CrossRef]

128. To, K.K.W.; Hung, I.F.N.; Ip, J.D.; Chu, A.W.H.; Chan, W.M.; Tam, A.R.; Fong, C.H.Y.; Yuan, S.; Tsoi, H.W.; Ng, A.C.K.; et al. Coronavirus Disease 2019 (COVID-19) Re-infection by a Phylogenetically Distinct Severe Acute Respiratory Syndrome Coronavirus 2 Strain Confirmed by Whole Genome Sequencing. Clin. Infect. Dis. 2020, 1-6. [CrossRef] [PubMed]

129. Anderson, E.J.; Rouphael, N.G.; Widge, A.T.; Jackson, L.A.; Roberts, P.C.; Makhene, M.; Chappell, J.D.; Denison, M.R.; Stevens, L.J.; Pruijssers, A.J.; et al. Safety and Immunogenicity of SARS-CoV-2 mRNA-1273 Vaccine in Older Adults. N. Engl. J. Med. 2020, 383, 2427-2438. [CrossRef] 
130. Sharma, O.; Sultan, A.A.; Ding, H.; Triggle, C.R. A Review of the Progress and Challenges of Developing a Vaccine for COVID-19. Front. Immunol. 2020, 11, 585354. [CrossRef] [PubMed]

131. Wan, Y.; Shang, J.; Sun, S.; Tai, W.; Chen, J.; Geng, Q.; He, L.; Chen, Y.; Wu, J.; Shi, Z.; et al. Molecular Mechanism for Antibody-Dependent Enhancement of Coronavirus Entry. J. Virol. 2019, 94, e02015-19. [CrossRef]

132. Quinlan, B.D.; Mou, H.; Zhang, L.; Guo, Y.; He, W.; Ojha, A.; Parcells, M.S.; Luo, G.; Li, W.; Zhong, G.; et al. The SARS$\mathrm{CoV}-2$ receptor-binding domain elicits a potent neutralizing response without antibody-dependent enhancement. bioRxiv 2020. [CrossRef]

133. Henry, P.G.; Clemente, M.; Fernando, M.; Ferdinando, L.; Juan, E.L.; Rosa, M.A. Antibody-dependent enhancement of dengue virus infection in U937 cells requires cholesterol-rich membrane microdomains. J. Gen. Virol. 2010, 91 Pt 2, $394-403$.

134. Morris, K.V. The Improbability of the Rapid Development of a Vaccine for SARS-CoV-2. Mol. Ther. 2020, 28, 1548-1549. [CrossRef] [PubMed]

135. Garber, K. Coronavirus vaccine developers wary of errant antibodies. Nat. Biotechnol. 2020. [CrossRef] [PubMed]

136. Zhang, Y.; Zeng, G.; Pan, H.; Li, C.; Hu, Y.; Chu, K.; Han, W.; Chen, Z.; Tang, R.; Yin, W.; et al. Safety, tolerability, and immunogenicity of an inactivated SARS-CoV-2 vaccine in healthy adults aged 18-59 years: A randomised, double-blind, placebo-controlled, phase $1 / 2$ clinical trial. Lancet Infect. Dis. 2021, 21, 181-192. [CrossRef]

137. Graham, B.S. Rapid COVID-19 vaccine development. Science (80-) 2020, 368, 945-946. [CrossRef] [PubMed]

138. Sharpe, H.R.; Gilbride, C.; Allen, E.; Belij-Rammerstorfer, S.; Bissett, C.; Ewer, K.; Lambe, T. The early landscape of coronavirus disease 2019 vaccine development in the UK and rest of the world. Immunology 2020, 160, 223-232. [CrossRef]

139. Corey, L.; Mascola, J.R.; Fauci, A.S.; Collins, F.S. A strategic approach to COVID-19 vaccine R\&D. Science (80-) 2020, 368, 948-950.

140. Deming, M.E.; Michael, N.L.; Robb, M.; Cohen, M.S.; Neuzil, K.M. Accelerating Development of SARS-CoV-2 Vaccines-The Role for Controlled Human Infection Models. N. Engl. J. Med. 2020, 383, e63. [CrossRef]

141. Folegatti, P.M.; Ewer, K.J.; Aley, P.K.; Angus, B.; Becker, S.; Belij-Rammerstorfer, S.; Bellamy, D.; Bibi, S.; Bittaye, M.; Clutterbuck, E.A.; et al. Safety and immunogenicity of the ChAdOx1 nCoV-19 vaccine against SARS-CoV-2: A preliminary report of a phase 1/2, single-blind, randomised controlled trial. Lancet 2020, 396, 467-478. [CrossRef]

142. Jiang, S. Don't rush to deploy COVID-19 vaccines and drugs without sufficient safety guarantees. Nature 2020, $579,321$. [CrossRef] [PubMed]

143. Alberer, M.; Gnad-Vogt, U.; Hong, H.S.; Mehr, K.T.; Backert, L.; Finak, G.; Gottardo, R.; Bica, M.A.; Garofano, A.; Koch, S.D.; et al. Safety and immunogenicity of a mRNA rabies vaccine in healthy adults: An open-label, non-randomised, prospective, first-in-human phase 1 clinical trial. Lancet 2017, 390, 1511-1520. [CrossRef]

144. Sebastian, M.; Papachristofilou, A.; Weiss, C.; Früh, M.; Cathomas, R.; Hilbe, W.; Wehler, T.; Rippin, G.; Koch, S.D.; Scheel, B.; et al. Phase $\mathrm{Ib}$ study evaluating a self-adjuvanted mRNA cancer vaccine (RNActive ${ }^{\circledR}$ ) combined with local radiation as consolidation and maintenance treatment for patients with stage IV non-small cell lung cancer. BMC Cancer 2014, 14, 748. [CrossRef]

145. Jacobson, J.M.; Routy, J.P.; Welles, S.; DeBenedette, M.; Tcherepanova, I.; Angel, J.B.; Asmuth, D.M.; Stein, D.K.; Baril, J.G.; McKellar, M.; et al. Dendritic cell immunotherapy for HIV-1 infection using autologous HIV-1 RNA: A randomized, double-blind, placebo-controlled clinical trial. J. Acquir. Immune Defic. Syndr. 2016, 72, 31-38. [CrossRef]

146. Safety and Immunogenicity Study of 2019-nCoV Vaccine (mRNA-1273) for Prophylaxis SARS CoV-2 Infection (COVID-19). Available online: https:/ / clinicaltrials.gov/ct2/show /NCT04283461 (accessed on 28 February 2021).

147. Mulligan, M.J.; Lyke, K.E.; Kitchin, N.; Absalon, J.; Gurtman, A.; Lockhart, S.; Neuzil, K.; Raabe, V.; Bailey, R.; Swanson, K.A.; et al. Phase I/II study of COVID-19 RNA vaccine BNT162b1 in adults. Nature 2020, 586, 589-593. [CrossRef]

148. Jackson, L.A.; Anderson, E.J.; Rouphael, N.G.; Roberts, P.C.; Makhene, M.; Coler, R.N.; McCullough, M.P.; Chappell, J.D.; Denison, M.R.; Stevens, L.J.; et al. An mRNA Vaccine against SARS-CoV-2-Preliminary Report. N. Engl. J. Med. 2020, 383, 1920-1931. [CrossRef]

149. Chulalongkorn University. ChulaCov19 mRNA Vaccine in Healthy Adults. 2020. Available online: https://clinicaltrials.gov/ct2 / show / NCT04566276 (accessed on 19 February 2021).

150. Chahal, J.S.; Khan, O.F.; Cooper, C.L.; McPartlan, J.S.; Tsosie, J.K.; Tilley, L.D.; Sidik, S.M.; Lourido, S.; Langer, R.; Bavari, S.; et al. Dendrimer-RNA nanoparticles generate protective immunity against lethal ebola, H1N1 influenza, and Toxoplasma gondii challenges with a single dose. Proc. Natl. Acad. Sci. USA 2016, 113, E4133-E4142. [CrossRef] [PubMed]

151. Chahal, J.S.; Fang, T.; Woodham, A.W.; Khan, O.F.; Ling, J.; Anderson, D.G.; Ploegh, H.L. An RNA nanoparticle Vaccine against Zika virus elicits antibody and CD8+ T cell responses in a mouse model. Sci. Rep. 2017, 7, 252. [CrossRef]

152. Weide, B.; Carralot, J.P.; Reese, A.; Scheel, B.; Eigentler, T.K.; Hoerr, I.; Rammensee, H.G.; Garbe, C.; Pascolowz, S. Results of the first phase I/II clinical vaccination trial with direct injection of mRNA. J. Immunother. 2008, 31, 180-188. [CrossRef]

153. Kübier, H.; Stenzl, A.; Schultze-Seemann, W.; vom Dorp, F.; Pilla, L.; Hampel, C.; Jocham, D.; Development, C.; Miller, K. 7046 POSTER Final Analysis of a Phase 1/lla Study With CV9103, an Intradermally Administered Prostate Cancer Immunotherapy Based on Self Adjuvanted mRNA. Eur. J. Cancer 2011, 47, S498-S499. [CrossRef] 